\title{
The impact of stakeholders' temporal orientaton on short- and long-term IPO outcomes: A meta-analysis
}

\author{
Peter-Jan Engelen $^{\mathrm{a}, \mathrm{b}}$, Pursey Heugens ${ }^{\mathrm{c}, *}$, Marc van Essen ${ }^{\mathrm{d}, \mathrm{e}}$, Roxana Turturea ${ }^{\mathrm{f}}$, \\ Nick Bailey ${ }^{g}$ \\ ${ }^{\mathrm{a}}$ University of Antwerp, Faculty of Business and Economics, Belgium \\ ${ }^{\mathrm{b}}$ Utrecht University, School of Economics, the Netherlands \\ ${ }^{\mathrm{c}}$ Rotterdam School of Management, Erasmus University, the Netherlands \\ ${ }^{\mathrm{d}}$ Moore School of Business, University of South Carolina, USA \\ ${ }^{\mathrm{e}}$ EM Lyon Business School, France \\ ${ }^{\mathrm{f}}$ Aalto University, Aalto School of Science, Finland \\ ${ }^{\mathrm{g}}$ University of Northern Iowa, USA
}

\begin{abstract}
A B S T R A C T
An initial public offering (IPO) represents a unique milestone in the lifecycle of a firm. Yet, our understanding of the IPO phenomenon remains incomplete and marked by mixed findings. Using meta-analytical techniques on a sample of 123 empirical studies, we examine the factors that influence the short-term outcomes (i.e., underpricing and proceeds) and the long-term outcomes (i.e., financial performance and risk) of IPO firms. Our efforts yield few significant results for antecedents that prior research had proposed as effective signals of IPO firm quality, and we thus conclude that signaling theory is limited in its ability to capture the IPO process. Our findings, however, provide preliminary support for our contention that stakeholders influence short-term IPO outcomes depending on their temporal orientation. We also find strong support for our prediction that the IPO has consequences for long-term firm development. While high underpricing positively affects long-term firm performance, it also heightens long-term firm risk. Large proceeds result in higher long-term firm performance and lower firm risk, but they come at the expense of a higher percentage of equity being traded during the IPO.
\end{abstract}

\section{Introduction}

An initial public offering (IPO) is a transition process through which a private company becomes public by offering part of its equity to public shareholders (Röell, 1996). It represents a unique milestone in the lifecycle of a firm, with long-term consequences for its behavior and performance (Chaddad and Reuer, 2009). A primary motivation for firms to undergo an IPO is to raise financial capital (Berger and Udell, 1998; Pagano et al., 1998; Ritter and Welch, 2002). Firms may use these financial resources to fund investments projects (e.g. acquisitions, R\&D, internationalization) or to repay debt obligations (Autore et al., 2009; Pagano et al., 1998). An equally important motivation for firms to undergo an IPO is to ensure a "stakeholder turnover", that is, to enable inside shareholders to sell (part of) their equity to new, public shareholders (Certo et al., 2001a). At the same time, new parties like underwriters and auditors will take up an interest in the firm (Jawahar and McLaughlin, 2001). Compared to private fundraising (e.g., financing from crowdfunding, business angels, or venture capitalists), public fundraising via an IPO presents several important advantages. First, an IPO enables a firm to raise a considerably higher amount of capital than other financing alternatives. The average IPO firm in USA raised 250 million USD in the 2001-2015 period (Ritter, 2014), compared to the average venture capital

\footnotetext{
${ }^{*}$ Corresponding author.

E-mail addresses: p.j.engelen@uu.nl (P.-J. Engelen), pheugens@rsm.nl (P. Heugens), marc.vanessen@moore.sc.edu (M. van Essen), roxana.turturea@aalto.fi (R. Turturea),nick.bailey@uni.edu (N. Bailey).
} 
round of less than 10 million USD (Nofsinger and Wang, 2011). Second, an IPO is accompanied by a substantial legitimacy gain for a firm (Ravasi and Marchisio, 2003). Third, and finally, post-IPO firms can access additional capital less expensively, and benefit from higher valuations as acquisition targets than comparable private firms (Certo et al., 2009; Ritter and Welch, 2002).

The IPO process fundamentally influences the firm's ability to sustain future firm performance and future firm risk (Ragozzino, 2016; Ritter and Welch, 2002). However, most prior research on IPOs is restricted to a narrow theoretical and short temporal scope (Tsang and Blevins, 2015). Traditionally, researchers have predominantly relied on signaling theory to explain IPO outcomes (Certo et al., 2001b; Deeds et al., 1997; Quintana-García and Benavides-Velasco, 2016; Ragozzino, Shafi and Blevins, 2018). IPO firms are faced with the challenge of convincing outside investors of their true quality because considerable information asymmetries exist between IPO issuers and outside investors (Daily et al., 2005). Signaling models posit that "certain variables or indicators send signals to potential investors about the capabilities and future value of firms", thus reducing information asymmetries between firms and outside investors (Deeds et al., 1997: 33). The underlying logic is that these signals are costly and difficult to imitate (Connelly et al., 2010), and as a result only firms that are of high quality (i.e., firms with a sound business model and good financial prospects) would employ them to differentiate themselves from their lower-quality counterparts.

When high-quality firms cannot convince investors of their quality by emitting credible signals before the IPO, they have two, not mutually exclusive, alternatives at their disposal. First, high-quality firms can pursue an "underpricing strategy", which entails compensating prospective investors for remaining uncertainty by underpricing their shares (Certo et al., 2009; Engelen and van Essen, 2010). Underpricing is commonly defined as the percent difference between the offer price of the IPO and the closing price at the end of the first trading day (Ibbotson et al., 1988; Ritter, 1998). Underpricing can be regarded as a reward offered to early investors, who experience a gain in share value at the end of the first day of trading. Second, high-quality firms can opt for a "seasoned offering strategy", an approach that involves deliberately offering a smaller equity share in the firm during the IPO and a larger equity share during subsequent financing rounds on the stock exchange. The rationale behind such a strategy is that firms can reap greater returns once their "true" value is revealed in the post-IPO period (Alavi et al., 2008). This strategy would also result in the firm raising lower proceeds, as fewer shares are made available for sale during the IPO to begin with. IPO proceeds represent the total amount of financial capital raised through the IPO, computed by multiplying the offering size (number of shares for sale during the IPO) with the offer price per share.

Our current understanding of the IPO process is limited in several ways. First, there is little consensus on how the factors that feature in signaling models, such as underwriter prestige (Agrawal and Cooper, 2010; Carter et al., 1998), retained equity (Li and McConomy, 2004; McBain and Krause, 1989), and board independence (Jain et al., 2008; Kroll et al., 2007) influence short-term IPO outcomes. An earlier meta-analysis on the antecedents of short-term IPO outcomes by Daily and colleagues (2003), for example, found little support for the effectiveness of antecedents commonly suggested by signaling theoreticians, with the exception of firm size and underwriter reputation. Second, the IPO literature mainly uses unidimensional measures of IPO success. While underpricing is the most prevalent measure used for short-term IPO performance, in their influential review paper Certo and colleagues (2009) make a plea for disentangling how signals of quality may differentially affect alternative short-term IPO outcomes, such as IPO proceeds. Third, the multi-stakeholder nature of the IPO process has received little attention. While the involvement of certain stakeholders does not extend far beyond the IPO moment itself, others remain involved with the firm long after it goes public (Carpenter et al., 2003; Pollock et al., 2010). Consequently, depending on their temporal orientation, stakeholders may favor and push for different short-term IPO outcomes (Arthurs et al., 2008; Bruton et al., 2010; Jia and Zhang, 2014). Yet our understanding of how stakeholders' temporal orientations influence IPO outcomes is currently underdeveloped. Fourth, we still only weakly understand the relationships between short- and long-term IPO outcomes, and the potential trade-offs between them (Certo et al., 2009; Tsang and Blevins, 2015). One such tradeoff exists between underpricing and the firm's risk-taking behavior. When firms deliberately underprice their shares with the intention of recouping their losses in the longer term (Grinblatt and Hwang, 1989; Welch, 1989), they will likely engage in more aggressive behavior after the IPO. However, we currently do not fully understand how 'leaving money on the table' (Ritter and Welch, 2002) influences long-term firm risk.

Our study makes three contributions to the IPO literature. First, we systematically re-examine the effect of signaling-based antecedents on short-term IPO outcomes. Recognizing that short-term IPO outcomes are multi-faceted (Certo et al., 2009), we link these antecedents to both IPO underpricing and IPO proceeds. Both underpricing and proceeds convey the perceptions of subscribers, in the sense that firms perceived as high quality should record lower underpricing and higher proceeds. However, these outcomes also capture the interests of pre-IPO owners. Firm insiders, such as founders and private investors, decide upon the offer price per share and on the offering size. They thus influence these short-term outcomes directly. Our findings indeed provide support for the view that the suitability of quality signals depends on the desired short-term performance outcomes. For instance, the pre-IPO performance of the firm positively affects the amount of proceeds raised during the IPO, but it does not guarantee lower underpricing. We hereby update and extend the earlier meta-analysis by Daily and her colleagues (2003).

Second, we use stakeholder theory (Freeman, 1984; Frooman, 1999; Jawahar and McLaughlin, 2001; Mitchell et al., 1997) to explain how stakeholders with different identities and temporal orientations shape investors' interpretations and affect IPO outcomes differently. Past research has predominantly interpreted stakeholders' involvement as an informational signal indicating IPO firm quality (Daily et al., 2003; Quintana-García and Benavides-Velasco, 2016). However, stakeholders have different and often conflicting interests in the IPO firm, and differ in their ability to realize these interests (Allcock and Filatotchev, 2010; Arthurs et al., 2008; Bruton et al., 2010; Dalziel et al., 2011). Consequently, depending on their temporal orientation, they push for divergent shortterm IPO outcomes, and may favor different long-term IPO firm strategies (Arthurs et al., 2008; Connelly et al., 2010; Jia and Zhang, 2014). We thus respond to the plea by Certo and colleagues, who "advise researchers to consider the stakeholders under examination-and their motives" (2009: 1363) when theoretically framing the IPO process. 
Third, we build on signaling theories (Connelly et al., 2011; Bergh et al., 2014) and on insights from behavioral economics (Bondt and Thaler, 1985; Thaler, 2015) to explore how the short-term IPO outcomes of underpricing and proceeds affect long-term firm risk and long-term firm performance. For long-term performance, we include both market-based measures (i.e., performance on the stock exchange) and accounting-based measures (e.g., ROA or ROE). Risk refers to the volatility of firm value in the aftermarket, which we refer to as long-term firm risk. For publicly listed firms, long-term risk is typically measured as the standard deviation of returns on the stock exchange, which conveys the riskiness of future cash-flows as perceived by public investors (Johnson and Miller, 1988; Carter et al., 1998; Wright et al., 2007). The more public investors perceive a firm to be engaging in risk-taking behavior, the more its share price will fluctuate on the market. From a signaling perspective, underpricing and proceeds are credible signals of quality for public investors that convey firm performance (Allen and Faulhaber, 1989; Grinblatt and Hwang, 1989; Welch, 1989). From a behavioral economics perspective, underpricing and proceeds shape firm behaviors in ways that will affect long-term firm risk and long-term firm performance. In so doing, we uncover the trade-offs IPO firms make to balance short- and long-term outcomes.

\section{Theory and hypotheses}

\section{Theoretical overview}

Prior IPO studies mostly built on signaling theory to explain IPO outcomes (Daily et al., 2003). Recently, however, researchers have introduced new theoretical perspectives that emphasize the diverging interests and influence over strategic decision-making of a variety of stakeholders during the IPO (Arthur et al., 2008; Dalziel, White and Arthurs, 2011). While these new perspectives broaden our understanding of the IPO process, few studies attempt to integrate and reconcile insights from more than one theoretical perspective (for notable exceptions, see Arikan and Capron, 2010, or Wang and Song, 2016). This is unfortunate, particularly because these different theoretical perspectives are complementary in that they can explain alternate or even opposite effects of stakeholder involvement on IPO outcomes.

Our study therefore seeks to offer a novel take on the IPO process by employing several complementary theoretical lenses. To examine the antecedents of IPO short-term performance, we build on signaling (Connelly et al., 2010) and stakeholder theories (Freeman, 1984; Frooman, 1999). In line with extant research on IPOs (Certo et al., 2001b; Deeds et al., 1997), we include several widely used signals of quality, such as pre-issue performance and pre-issue uncertainty. We diverge from the predictions of signaling theory when examining the role of pre-issue stakeholders. While these parties are often treated as signals of quality in prior studies, recent research has highlighted the need to also consider their identity and interests (Certo et al., 2009; Dalziel, White and Arthurs, 2011; Pollock et al., 2010). The temporal orientation of stakeholders is particularly revelatory to capture their varying and oftentimes conflicting interests. We therefore follow Arthur and colleagues (2008) and Jia and Zhang (2014) to differentiate between stakeholders with a short-term orientation (i.e., venture capitalists, reputable underwriters, and reputable auditors) and those with a longterm orientation (i.e., institutional investors, CEO founders, and retained owners). We then proceed to theorize how, depending on their temporal orientations, these stakeholders push for different short-term outcomes. Employing stakeholder theory especially helps us to understand the influence of long-term stakeholders. Signaling theory would predict that the inclusion of these long-term stakeholders would benefit short-term performance (and thus reduce underpricing and increase proceeds). Stakeholder theory enables us to understand that when the involvement of long-term stakeholders does not lead to improved short-term IPO performance, this does not automatically mean that their inclusion does not signal quality. In contrast, these stakeholders do not prioritize shortterm IPO outcomes, and are willing to forfeit short-term returns in order to secure better long-term IPO outcomes.

To disentangle the long-term consequences of short-term IPO outcomes, we build on signaling theories (Allen and Faulhaber, 1989; Grinblatt and Hwang, 1989; Welch, 1989) and behavioral economics (Bondt and Thaler, 1985; Thaler, 2015). More specifically, our theorizing concerning long-term IPO outcomes entails two fundamental mechanisms. The first mechanism again involves signaling and focuses on insiders' attempts to reduce information asymmetries with outsiders like public investors. Under this logic, IPO firms resort to signals of quality to convince potential investors of their "true" quality. While most IPO research emphasizes the signals that shape short-term IPO outcomes, firms continue to signal their quality, albeit under conditions of lower information asymmetry, after the IPO as well. Signaling post-IPO can help firms to complete successful seasoned offerings (Alavi et al., 2008). Even when firms do not plan on seasoned offerings, effective signaling helps maintain shareholders' positive perceptions and secure firm value. The second mechanism is behavioral and highlights how insiders' decisions ultimately affect the long-term risk and longterm performance of their firms. We build on behavioral economics (Bondt and Thaler, 1985; Thaler, 2015), to untangle how insiders respond to different levels of short-term IPO outcomes, which shape their firms' resource endowments. Fig. 1 presents these conceptual ideas.

\section{Information asymmetries, underpricing and proceeds}

IPO firms have to overcome information asymmetries between themselves as issuers and potential new investors (Certo et al., 2009). IPO insiders have access to better information about the quality of their firm and its future prospects than outsiders (i.e. public investors), making it difficult for the latter to accurately value the firm (Akerlof, 1970; Leland and Pyle, 1977; Ritter, 1998). Signaling theorists suggest that insiders will seek to overcome these information asymmetries by adopting credible and difficult to imitate signals that showcase the true quality of their firm (Certo et al., 2001b; Deeds et al., 1997; Quintana-García and Benavides-Velasco, 2016). In doing so they aim to reduce underpricing and enlarge IPO proceeds. Prior research has examined the impact of several antecedents on the ex ante uncertainty surrounding IPO firms. Many studies examine factors listed in the firm's prospectus, which is publicly available and reliable, as company insiders, auditors, and underwriters certify this information and are legally responsible 


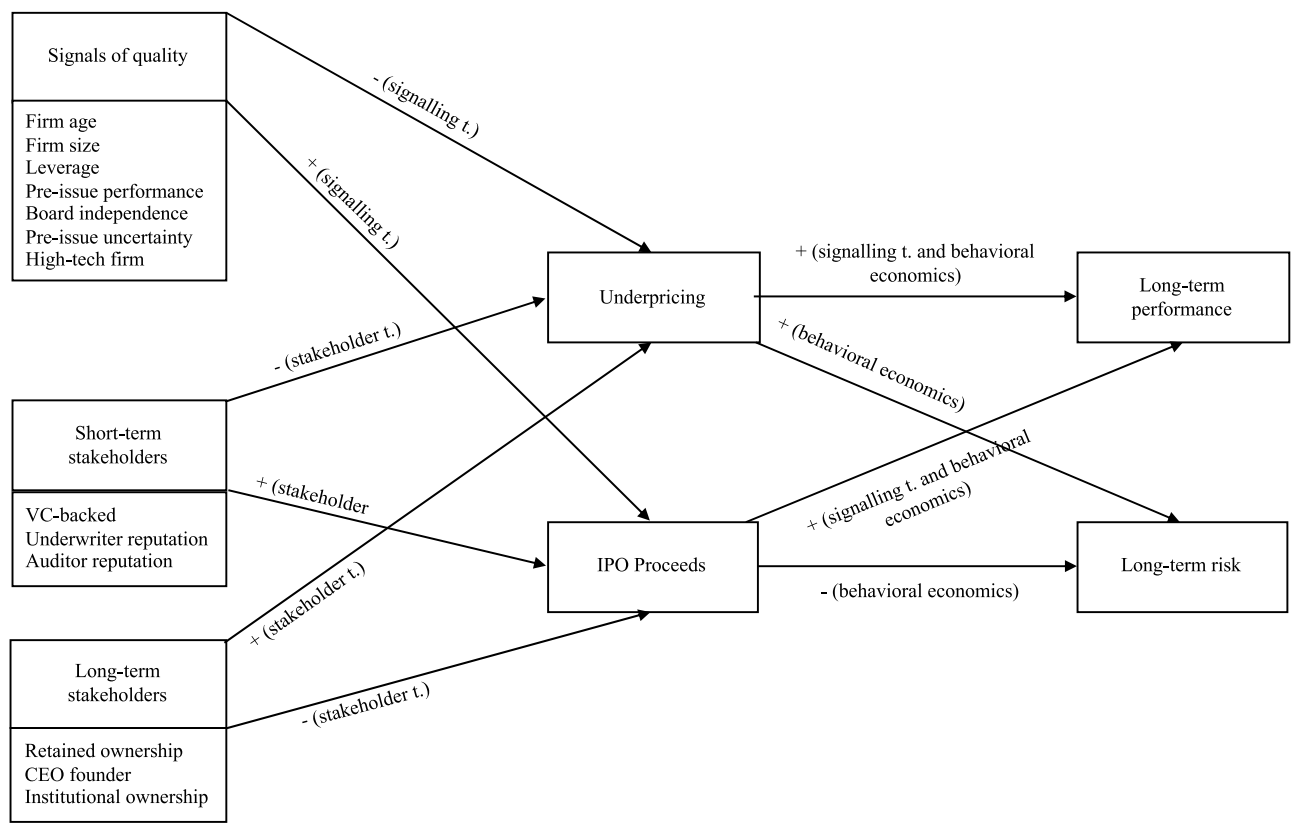

Fig. 1. Conceptual model.

for its accuracy (Certo et al., 2009; Daily et al., 2003; Tinic, 1988).

\section{Information asymmetries and underpricing}

Research indicates that, when ex ante uncertainty is high, IPO firms have to underprice their shares more to compensate for information asymmetries (Certo et al., 2009; Clarkson, 1994; Engelen and van Essen, 2010). When insiders attempt to overprice their shares, they are unlikely to raise sufficient interest among prospective investors. Several signals have the potential to reduce uncertainty about the IPO firm's future value. One is company age (Daily et al., 2003). As more information is available for older firms, ex ante uncertainty about them is lower (Carter et al., 1998; Ritter, 1998). Older firms also face lower failure risk (Freeman et al., 1983). Consequently, company age should reduce underpricing. Another factor is company size. Larger firms have more resources at their disposal to sustain their survival and growth (Finkle, 1998), thus reducing the uncertainty surrounding their IPOs. Leverage can also reduce underpricing. Debt investors rigorously evaluate firms that apply to them for debt funding, and only offer funds to firms they consider financially sound. Particularly when granting substantial loans, debt investors prefer firms with substantive collateral assets, low volatility, and easy to valuate business models (Barry and Mihov, 2006). Thus, high leverage signals prior scrutiny by debt investors that have vested interests in the IPO firm (James and Wier, 1990). Prior research also suggests that highly leveraged firms experience less underpricing (Barry and Mihov, 2006; James and Wier, 1990).

Other factors that can alleviate information asymmetries and thus reduce underpricing abound. Strong prior performance testifies to the quality of the firm and possibly decreases underpricing (Clarkson, 1994; Daily et al., 2005). Board independence can play a similar role, as it signals that IPO firms employ effective monitoring and control systems (Daily et al., 2005; Jain et al., 2008). Highquality IPO firms are also more likely to attract outside directors than low-quality firms, as the presence of outsiders on the board signals the mitigation of selection problems. Another factor is pre-issue uncertainty, typically represented by the number of risk factors included in the IPO prospectus (Certo et al., 2001a). Pre-issue uncertainty can exacerbate concerns about the future prospects of the firm (Beatty and Zajac, 1994; Clarkson, 1994). Firms with lower pre-issue uncertainty are therefore less inclined to underprice (Daily et al., 2003). Still another challenge involves firms with a business model built on a high-technology platform. Firms in hightechnology industries involve knowledge asymmetries between expert insiders and lay investors, and may have to underprice their shares accordingly (Engelen, 2003; Ljungqvist and Wilhelm, 2003). In sum, the presence of IPO firm characteristics that reduce information asymmetries about firm value reduces underpricing. See Hypothesis 1a:

Hypothesis 1a. Signals that reduce information asymmetries between issuers and investors curtail underpricing.

\section{Information asymmetries and proceeds}

In addition to investigating the antecedents of underpricing, we also explore those of IPO proceeds for two key reasons. First, underpricing and proceeds are distinct measures of IPO success and investigating them in tandem provides a more comprehensive picture of IPO outcomes (Certo et al., 2009; Gulati and Higgins, 2003). Second, from the perspective of IPO firm insiders, underpricing and proceeds have different strategic objectives: underpricing is related to pricing accuracy or avoiding the transfer of wealth 
from pre-IPO owners to new owners, whereas proceeds involve capital raising or the acquisition of pecuniary resources to finance new initiatives or restructure existing obligations (Autore et al., 2009; Certo et al., 2009; Pagano et al., 1998).

We also expect IPO proceeds to be influenced by ex ante information asymmetries, albeit sometimes in different ways. First, when there are fewer asymmetries, high quality firms are more likely to target larger offerings because they expect favorable valuations from prospective investors. High-quality firms of proven value, as signaled by aspects like size, leverage, or pre-issue performance, will also avoid smaller issues as they have access to other sources of finance for smaller investments (Certo et al., 2009; Ritter, 1987). Second, when information asymmetries are lower, such as when firms have more independent board members or a proven track record of strong performance, it is easier for underwriters, auditors, venture capitalists, and other gatekeepers to determine the quality of IPO firms (Benveniste and Spindt, 1989; Daily et al., 2003). When such gatekeepers put their reputations on the line by associating themselves with the IPO, the demand for the firm's shares tends to go up (Beatty and Ritter, 1986; Titman and Trueman, 1986). Third, when information asymmetries are high, such as in high-technology industries, excellent firms may be reluctant to opt for large IPO offerings, as predictably high levels of underpricing will result in a good deal of money being left on the table. Instead, these firms favor smaller initial offerings, followed by larger seasoned offerings when the true value of the firm is easier to signal (Alavi et al., 2008). Therefore, we expect that IPO firm characteristics that limit ex ante uncertainty will lead to higher proceeds. See Hypothesis $1 \mathrm{~b}$ :

Hypothesis 1b. Signals that reduce information asymmetries between issuers and investors increase proceeds.

\section{Toward a stakeholder-centric view of the IPO process}

Several scholars have paid attention to the role of stakeholders in influencing short-term IPO outcomes (Bruton et al., 2010; Cohen and Dean, 2005; Higgins and Gulati, 2006; Jain et al., 2008). To date, however, most have sought to embed stakeholder influences in signaling models, thereby reducing stakeholder involvement to the short-run information signals they emit (Beatty and Welch, 1996; Carter and Manaster, 1990; Sanders and Boivie, 2004). However, pure signaling models are no substitute for a truly stakeholdercentric theory of the IPO process for two reasons. First, these models assume that public investors make decisions based on status-quo considerations and disregard the longer-term implications of stakeholder involvement (Pollock et al., 2010). Stakeholders that leave the company shortly after the IPO provide a signal of the quality of the firm at the moment of the IPO, but do not substantively contribute to the firm's post-IPO success. As such, the involvement of these stakeholders at the moment of the IPO does not correct information asymmetries related to the firm's long-term prospects. Second, signaling models do not account for the fact that different stakeholder groups face different incentives in the IPO process and push for different outcomes (Bruton et al., 2010; Wang and Wan, 2013). We therefore propose a stakeholder-centric view of the IPO process (Freeman, 1984; Jawahar and McLaughlin, 2001) to complement signaling models.

In particular, we frame the IPO as a multi-stakeholder process, involving not only issuers with equity to sell and investors seeking investment opportunities, but also a host of other parties with an interest in the firm. Moreover, going public has a clear temporal dimension. First, an IPO is a specific moment in the life cycle of the firm (Berger and Udell, 1998). After securing funding through sources such as venture capital and private placements, IPO firms move to tapping into public equity. This public phase has two milestones: the IPO moment and seasoned equity offerings (SEO) at later moments, as firms typically return to public equity markets within three years of their IPO (Jegadeesh, Weinstein, Welch, 1993).

IPOs play an important role in the investment strategy of VC firms, as going public is their preferred exit strategy (Nofsinger and Wang, 2011). VCs enter the IPO firm on average three years earlier, and will exit the firm at the IPO moment or six months later at the expiration of the lock-up agreement. Gompers (1995) finds that the duration between the first VC investment and the IPO moment is on average 34 months, while Giot and Schwienbacher (2007) find an average duration of 1219 days on the US market. Cumming and Johan (2010) finds an average duration of 2.45 years for Canadian firms, while European firms typically have an average time between VC investment and the IPO of 3.7 years (Schwienbacher, 2008). VCs thus exit the firm no later than 6 months after the IPO. This contrasts with CEO founders, retained owners, and pre-IPO institutional investors. These parties tend to remain associated with the firm long after the IPO moment.

Other stakeholders also only commit to the IPO firm during specific temporal windows. Auditors typically enter the firm's sphere twelve months prior to the IPO and exit at the IPO moment (Draho, 2004; EY, 2013). Underwriters typically appear six months prior to the IPO moment. They exit the firm shortly after the IPO moment (Corwin and Schultz, 2005), as they perform price support for two to four days (Ruud, 1993) and typically have the option to acquire extra shares by exercising the overallotment option (green shoe) within 30 days after the IPO (Draho, 2004). The IPO is therefore a clear exit moment for venture capitalists, auditors and underwriters, through which they leave the firm's stakeholder group.

We follow Arthur and colleagues (2008) and Jia and Zhang (2014) to differentiate between stakeholders with a short-term orientation (i.e., venture capitalists, reputable underwriters, and reputable auditors) and those with a long-term orientation (i.e., institutional investors, CEO founders, and retained owners). Fig. 2 summarizes the typical entry and exit moments of different stakeholders.

\section{Short-term orientation, underpricing and proceeds}

Several studies have suggested that the presence of venture capitalists (Bruton et al., 2010; Megginson and Weiss, 1991), reputable underwriters (Carter and Manaster, 1990; Chen and Mohan, 2002), and prestigious auditors (Beatty and Welch, 1996) can serve as a signal of the high quality of a firm. What ties these three stakeholder groups together is their comparatively short-term 


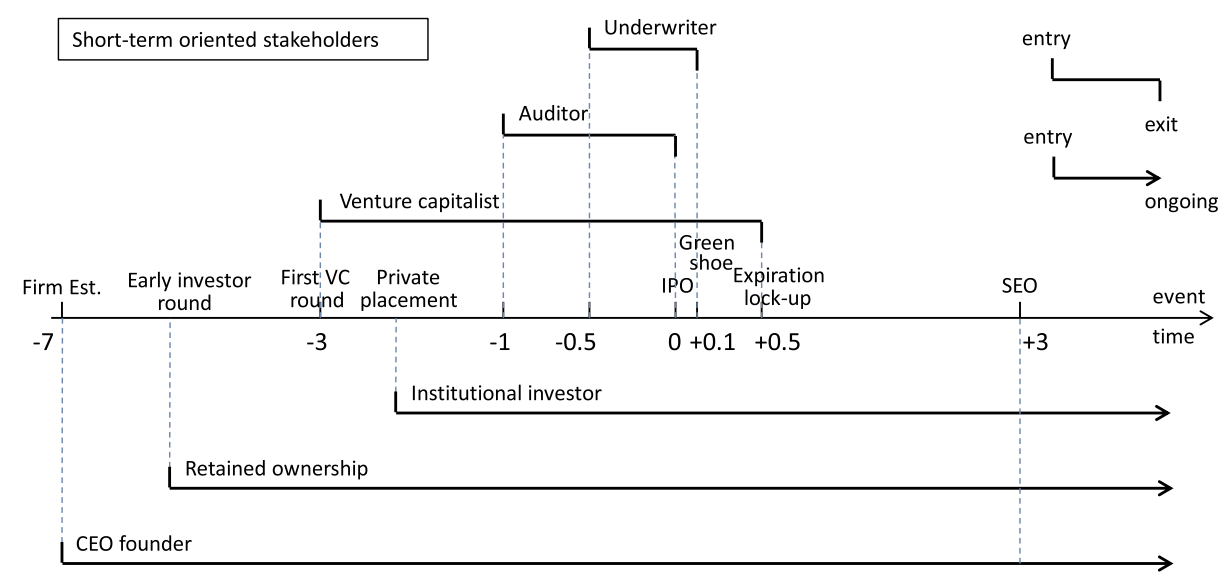

Long-term oriented stakeholders

Fig. 2. Temporal orientation of the different stakeholders involved in the IPO process.

Legend: The IPO moment is time 0 . All other moments expressed as years prior to or past the IPO date.

Sources: The duration between firm establishment and IPO (Loughran and Ritter, 2004), VC entry and exit moment (Gompers, 1995; Giot and Schwienbacher, 2007; Cumming and Johan, 2010; Schwienbacher, 2008), early round investors and private placement moments (Berger and Udell, 1998), auditor entry and exit moment (Draho, 2004; EY, 2013), underwriter entry and exit moment (Draho, 2004; EY, 2013; Ruud, 1993), SEO (Welch, 1996; Jegadeesh, Weinstein, Welch, 1993).

focus, as they often cease to do business with the focal firm shortly after the IPO (in the case of underwriters and auditors) or shortly after the lock-up period (in the case of venture capitalists).

Venture capitalists seek to invest in firms for a limited time period only, and often use IPOs to facilitate their exit (Arthur et al., 2008; Bascha and Walz, 2001; Cumming and MacIntosh, 2003; Pollock et al., 2010). Even when venture capitalists do not sell all their shares during the IPO, they tend to sell more rapidly and aggressively than other shareholders after the lock up period expires (Arikan and Capron, 2010; Field and Hanka, 2001). The backing of venture capitalists signals the quality of the IPO firm (Daily et al., 2005; Gulati and Higgins, 2003). Since venture capitalists' returns are closely related to the performance of the companies in which they invest, they are more likely to emphasize due diligence and only invest in companies they believe to be of high quality. Venture capitalists also bring substantive benefits to companies by providing advice on strategic decision-making (Meglio, Destri, and Capasso, 2017), access to key resources (Cyr et al., 2000; Wang and Wan, 2013), networks (Pollock et al., 2008), and high quality managers (Gorman and Sahlman, 1989). As venture capitalists tend to sell their shares during or shortly after the IPO, their interests are tied to short-term IPO outcomes, so they seek to reduce underpricing and increase IPO proceeds.

Underwriters affect IPO outcomes by putting their own reputation on the line to vouch for the quality of the IPO firm (Gulati and Higgins, 2003; Hegde and Varshney, 2003; Ritter and Welch, 2002). Underwriters' future business depends on the reputation that they have in the eyes of prospective IPO firms. This creates an incentive for underwriters to reduce underpricing, as issuers are averse to leaving money on the table. When underwriters seek to benefit their institutional investor clients by excessively underpricing an IPO firm's shares to the detriment of the firm's original owners, prospective IPO firms may not want to collaborate with them in the future. Furthermore, the underwriter's fee is typically a percentage of IPO proceeds (Chen and Ritter, 2000). We therefore expect underwriters to limit underpricing and increase proceeds.

We believe that the incentives to push for these short-term outcomes are even more pronounced for well-reputed underwriters. Prior research has shown that underwriters influence IPO short-term outcomes by signaling the quality of the firm (Benveniste and Spindt, 1989; Carter and Manaster, 1990; Megginson and Weiss, 1991). Well-reputed underwriters send more credible signals of quality as compared to less-reputable underwriters, and thus should be better able to facilitate short-term IPO success (Jia and Zhang, 2014). Given the importance of their reputation, underwriters seek to protect and maintain this valuable asset (Pollock, 2004) by considering the reputational consequences of becoming the lead underwriter of a firm (Ferris et al., 1992). Moreover, reputable underwriters not only fulfill a certification function, they also add substantive value to IPO firms. Because well-reputed underwriters have access to a wider network of institutional investors, they are less likely to be left with unsold shares and more willing to target larger IPO offerings (Benveniste and Spindt, 1989). Similarly, because reputable underwriters benefit from more embedded ties with institutional investors (Pollock, 2004), they are also more likely to obtain a more accurate IPO firm evaluation from these investors in the pre-market phase. This will be reflected in the IPO offering share price and reduce underpricing. Well-reputed underwriters thus face high-powered incentives to produce short-term IPO success.

Auditor involvement also tends to be limited to the IPO period. During the IPO process, the issuer has to produce a prospectus containing financial statements and financial information that require auditor verification (Firth and Liau-Tan, 1998). The reputation of the auditor would be negatively affected by a failure to reveal negative information about the company (Daily et al., 2003). The involvement of a well-reputed auditor thus sends a positive signal to investors, as only high quality firms should be able to secure one (Chang et al., 2007; Titman and Trueman, 1986). Lower-quality companies cannot imitate this signal, as well-reputed auditors are 
more likely to report information conveying the firm's weaknesses. We believe that reputable auditors in particular have both the incentive and the ability to enhance short-term IPO performance. Reputable auditors are concerned with protecting and maintaining their reputation, and thus prefer to associate themselves with successful IPOs (i.e., IPOs that record low underpricing and high proceeds). At the same time, they can support IPO firms in achieving favorable IPO outcomes, by providing more precise accounting information compared to their less reputable counterparts (Beatty, 1989; Chang et al., 2007). High-quality accounting information reduces information asymmetries between issuers and public investors, which reflects positively on short-term IPO outcomes (Beatty, 1989). See Hypotheses 2a and 2b:

Hypothesis 2a. The involvement of stakeholders with a short-term orientation curtails underpricing.

Hypothesis $\mathbf{2 b}$. The involvement of stakeholders with a short-term orientation increases proceeds.

\section{Long-term orientation, underpricing and proceeds}

As stakeholders with a longer-term orientation strive to remain associated with the firm after the IPO, they value long-term performance more than venture capitalists, underwriters, or auditors. Their future wealth depends on the accumulation of profits and dividends, and thus on the equity they retain in the firm. These stakeholders therefore have less interest in maximizing proceeds, and seek to retain as much equity with corresponding future cash flow rights as they can. They are also less concerned about underpricing, as they anticipate that underpricing increases the chances of a fully subscribed IPO and helps to turn their long-term value-maximizing strategy into a success (Allen and Faulhaber, 1989). We focus on three stakeholder groups with long-term intent: CEO founders (Certo et al., 2001a; Nelson, 2003), retained owners (McBain and Krause, 1989; Reber et al., 2005), and institutional investors (Sanders and Boivie, 2004).

We expect CEO founders to be less concerned about underpricing and to avoid maximizing proceeds at all costs. CEO founders tend to be less interested in maximizing IPO proceeds than pursuing longer-term goals and will thus be more inclined to sell a smaller percentage of the firm's equity during the IPO (Nelson, 2003). Because of their long-term focus, CEO founders have the option of attracting additional investment via seasoned offerings at more favorable valuations at a later stage (Certo et al., 2001a, 2009). To ensure the full subscription of their IPOs, they tend to resort to the instrument of underpricing (Allen and Faulhaber, 1989). Successful seasoned offerings could guarantee CEO founders not only an increase in managerial compensation, but also a better valuation of their retained equity. Since CEO founders hold a larger equity stake than non-founder CEOs (Nelson, 2003), they are also set to benefit more from seasoned offerings at more advantageous valuations.

The involvement of retained owners (i.e., firm insiders that retain an equity holding in the firm long after the IPO) may similarly lead to more underpricing, as this signals that influential insiders are optimistic about the future prospects of the firm. For shareholders of lower-quality companies, retaining equity is a costly signal to send, as they may not be able to sell their shares on equally favorable terms later. Thus, only shareholders of high-quality companies would be willing to retain ownership while increasing underpricing at the IPO moment (Reber et al., 2005; McBain and Krause, 1989). Retained ownership similarly corresponds to a wealth-maximization strategy focused on lower initial proceeds and seasoned offerings at a later stage.

Institutional investors (i.e. the percentage of equity owned by institutional investors prior to the IPO) also serve as a certification tool (Sanders and Boivie, 2004). 'Dedicated' institutional investors (Bushee, 2001) employ professional analysts, specialized in screening and monitoring firm performance, which makes them informed investors (Bethel and Liebeskind, 1993). Their influence on strategic decision-making also contributes to the quality of governance in IPO firms (Pound, 1992). Dedicated institutional investors are not primarily interested in maximizing short-run IPO proceeds. For them, the IPO is not an opportunity to enact an exit strategy, but rather a way to create another governance channel. Institutional investors can exercise greater influence over the firm's management when they are able resort to the pressure-inducing mechanism of dumping their shares in the event that the company's management is unresponsive to their demands. Dedicated institutional investors are therefore less inclined to pursue large proceeds and are less concerned about underpricing. See Hypotheses $2 \mathrm{c}$ and $2 \mathrm{~d}$ :

Hypothesis 2c. The involvement of stakeholders with a long-term orientation increases underpricing.

Hypothesis 2d. The involvement of stakeholders with a long-term orientation reduces proceeds.

\section{Reconciling short and long-term IPO outcomes}

A question that has largely been neglected by the IPO literature is how short-term IPO outcomes influence long-term firm performance and long-term firm risk. Underpricing and proceeds determine the resource endowment and trigger responses from the focal firm that impact long-term outcomes (Chan et al., 2004; van der Zahn et al., 2007; Wiseman and Bromiley, 1996).

\section{Underpricing and long-term firm performance}

On average, the sum left on the table as a result of underpricing tends to exceed three times the company's profits in the year preceding the IPO (Loughran and Ritter, 2002). Underpricing therefore seems inherently undesirable. Yet, from a signaling perspective, it is also a difficult to imitate signal of quality, telling potential investors that insiders have confidence in the company's long-term prospects (Allen and Faulhaber, 1989; Grinblatt and Hwang, 1989; Hill and Wilson, 2006; Loughran and Ritter, 2002; Welch, 1989). High-quality companies could therefore use underpricing to reduce information asymmetries and distinguish themselves from lower-quality counterparts. For lower-quality firms, increased underpricing is not a viable option because once their 'true 
value' is revealed in the aftermarket, these firms will not be able to recoup the losses incurred at the IPO moment (Allen and Faulhaber, 1989; Espenlaub and Tonks, 1998; Grinblatt and Hwang, 1989).

Firms that pursue a seasoned offerings strategy need to signal to outside investors that the firm is on a high post-IPO growth path (Jain, Jayaraman, and Kini, 2008). Securing funding through seasoned equity rounds under favorable conditions will support future firm growth prospects, as the firm will be able to execute more positive net present value projects. Growth seems to be a vital indicator of a firm's viability and survival (Holcomb et al., 2010). We therefore expect that underpricing will signal higher long-term firm performance, as obtaining equity funding is expected to increase the probability of post-IPO profitability (Jain et al., 2008). Without this funding the firm might not be able to achieve its profitability milestones.

Prior research indeed suggests that, over the longer term, underpricing is often compensated for with the use of seasoned offerings. Welch (1989) shows that from his sample of IPO firms listed between 1977 and 1982, one third reissued equity by 1986, with the average offering being three times larger than the IPO offering. Prior studies have shown that companies that underprice their shares are more likely to re-issue equity in the first three years after the IPO (Jegadeesh, Weinstein and Welch, 1993) and to raise a greater the amount of capital during seasoned offerings (Su and Fleisher, 1999). Underpricing is therefore a credible signal that firms are able to achieve their profitability milestones. See Hypothesis 3a:

Hypothesis 3a. IPO underpricing is positively associated with improved long-term firm performance.

\section{Underpricing and long-term firm risk}

Signaling models suggest that underpricing leads to more information being available in the after-market phase (Li et al., 2005; Ragozzino, 2016), which should reduce long-term firm risk. However, while underpricing signals higher expected long-term firm performance to outsiders, the standard deviation (volatility) around the expected present value of the cash flows also increases. Although investors expect a higher mean long-term-performance, Holcomb et al. (2010) find that the ex-post variation of profitability increases among underpricing firms. Long-term firm risk increases for three reasons. First, the "liability of newness" makes new ventures "more vulnerable to environmental conditions following their transition from private to public capital markets" (Holcomb et al. (2010: 360). This might be especially true for high-growth firms relying on seasoned offerings strategies (Jain et al., 2008).

Second, underpricing is very costly signaling device, as the amount of money left on the table represents a substantial short-term loss of cash infusion for the focal firm. As firms on a high growth path are mostly cash-constrained (Gilbert, McDougall, and Audretsch, 2006; Delmar, Davidsson, and Gartner, 2003), they must generate additional capital internally by seeking revenues from projects with higher risk profiles (Alvarez and Busenitz, 2001), such as product diversification and mergers and acquisitions (Certo et al., 2009).

Third, as underpricing sends a signal of firm quality to investors, companies planning seasoned offerings may be inclined to pursue riskier projects with greater expected returns to meet investors' expectations about post-IPO performance. This might be especially true as many IPO firms engage in earnings management by opportunistically inflating their earnings prior to going public (Teoh, Welch, and Wong, 1998). Such tactics raise pressure for realizing investors' expectations and increase post-IPO firm risk. A hidden cost of this strategy is that it induces IPO firms to forego long-term investments in innovation, as these will have an adverse effect on short-term firm valuation and performance (Heeley et al., 2007). We thus expect underpricing to result in higher post-IPO firm risk. See Hypothesis 3b:

Hypothesis $\mathbf{3 b}$. IPO underpricing is associated with greater long-term risk.

\section{Proceeds and long-term firm performance}

We expect the relationship between IPO proceeds and long-term firm performance to be positive for two reasons. First, from a signaling perspective, high IPO proceeds can constitute a credible signal of quality for firms in the post-IPO period when dealing with key stakeholders, such as new public investors (during seasoned offerings), suppliers, or banks. Higher IPO proceeds are a difficult-toimitate signal, as the amount of proceeds conveys the perceptions of quality of public investors at the time of the IPO (Certo et al., 2009). Low quality firms cannot raise high proceeds, because they will not be able to find a reputable underwriter to manage their IPO (Gordon and Jin, 1993). Even if low-quality firms attract an underwriter, they still tend to experience under subscription, which results in lower proceeds. Second, companies can also use proceeds to finance projects with high expected returns that were previously out of their financial reach (Berger and Udell, 1998). Leone, Rock, and Willenborg (2007) report that IPO firms earmark $29.7 \%$ of their proceeds for investments in areas like R\&D and the development of novel product lines. These investments will positively affect long-term performance. See Hypothesis 3c:

Hypothesis 3c. Greater IPO proceeds are positively associated with improved long-term performance.

\section{Proceeds and long-term risk}

We expect that large IPO proceeds will change the behavior of firms in ways that will decrease long-term firm risk. First, due to the additional capital available to repay debt, companies with higher IPO proceeds tend to lower their default risk (Leone et al., 2007; Pagano et al., 1998). Daily and colleagues indeed indicate that " $[\mathrm{e}]$ ntrepreneurs routinely leverage themselves to a point where they are unable to further increase either their own or the firm's debt load" (Daily et al., 2003: 273). Leone et al. (2007) found that, on average, IPO firms spend $38.1 \%$ of their proceeds on debt repayment. Consequently, Pagano and his colleagues (1998) report that companies reduce their leverage by $5.7 \%$ in the first four years after an IPO. Second, companies with greater IPO proceeds can invest 
Table 1

Description of the sample.

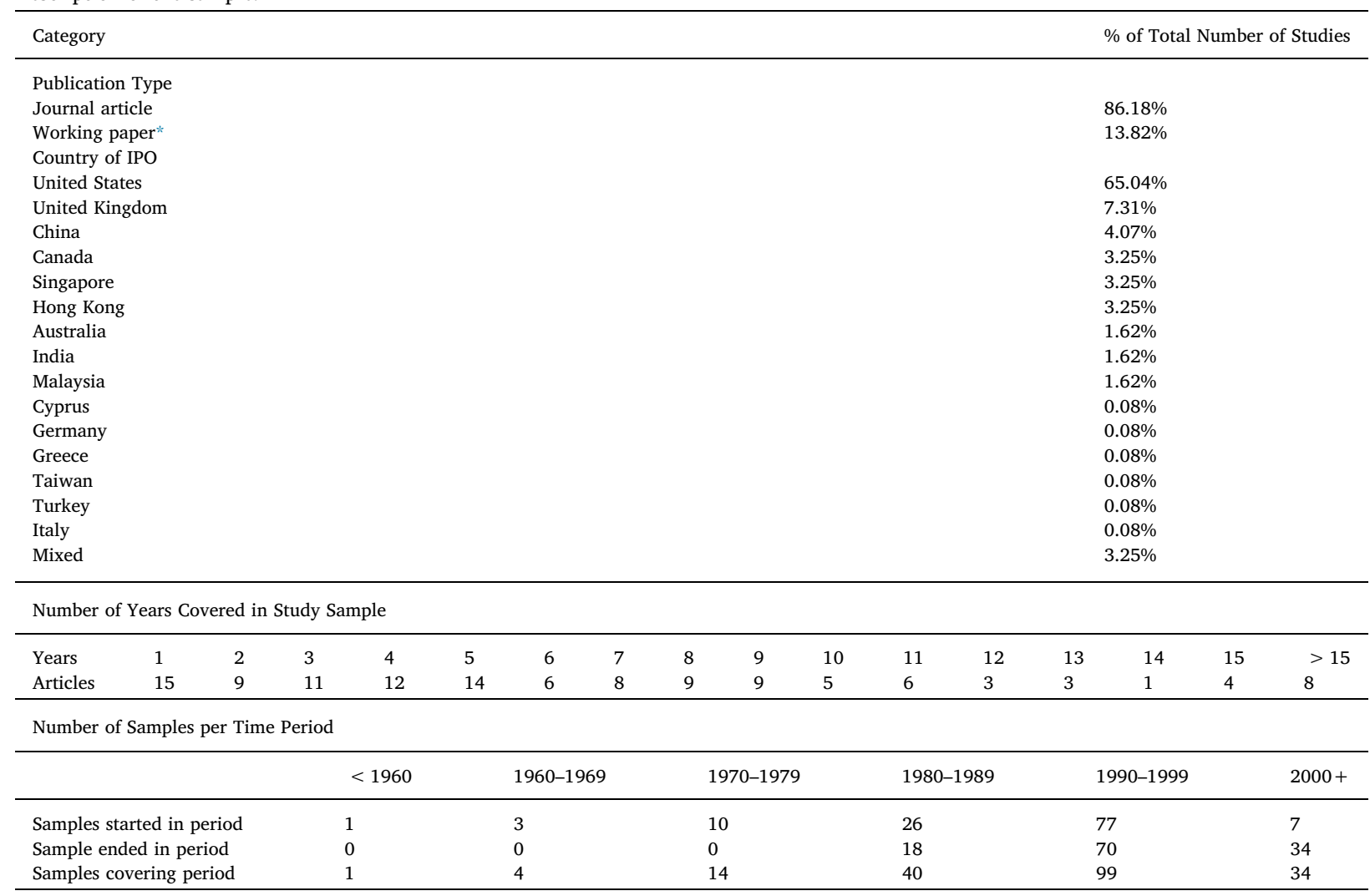

*Includes other unpublished works including dissertations and conference presentations.

in a more diverse portfolio of projects and in novel product lines (Morrow et al., 2007), thereby reducing the risk associated with nondiversified revenue streams (Ljungqvist, 2007). Third, higher proceeds produce more extensive slack resources, which enable companies to cope with internal challenges and adapt to changes in the external environment more quickly (George, 2005), thereby reducing overall firm risk. See Hypothesis 3d:

Hypothesis3d. Greater IPO proceeds are negatively associated with long-term risk.

\section{Methods}

\section{Sample and coding}

We used five complementary search strategies to identify IPO studies. First, we read two review articles (Certo et al., 2009; Ljungqvist, 2007) and one prior meta-analysis (Daily et al., 2003). Second, we examined five electronic databases: (1) ABI/INFORM Global, (2) EconLit, (3) Google Scholar, (4) JSTOR and (5) SSRN using the following search terms: 'IPO'; 'initial public offering' and 'underpricing'. Third, we manually searched 15 journals that frequently publish IPO research: Academy of Management Journal, Contemporary Accounting Research, Entrepreneurship Theory and Practice, Financial Management, Journal of Banking and Finance, Journal of Business Venturing, Journal of Business Finance and Accounting, Journal of Corporate Finance, Journal of Economics and Finance, Journal of Financial Economics, Journal of Management, Management Science, Organization Science, Small Business Economics, and Strategic Management Journal. Fourth, for each identified study, we traced its citation 'ancestry' and 'progeny' (Cooper, 1998) using Google Scholar and ISI Web of Knowledge. Fifth, we corresponded with 135 researchers who had published IPO papers with incomplete effect size information, asking them for a correlation table and for unpublished studies. We then checked for sampling overlap, and deleted all primary studies sharing an identical sample with a previously published study. These procedures strategies yielded a final sample of 123 primary studies (see reference list). Table 1 provides a description of the samples underlying these studies, including an overview of the countries the IPO firms are from and the time period during which these firms were under investigation.

To reduce concerns about publication bias, we included as many unpublished studies as we could retrieve online or through private correspondence with IPO authors; in the final sample, $13.82 \%$ of studies are unpublished. In line with Dalton and colleagues 
Table 2

Description of variables.

\begin{tabular}{|c|c|}
\hline Variables & Description \\
\hline Pre-issue uncertainty & $\begin{array}{l}\text { Number of risk factors listed in IPO firm prospectuses (Certo et al., 2001a) or an index of specific risk factors (Dow and } \\
\text { Martens, 2007). Also measured as the standard deviation of returns pre-IPO }\end{array}$ \\
\hline High-tech firms & $\begin{array}{l}\text { Typically a dummy variable for firms in industries such as information technology (Filatotchev and Bishop, 2002), computer } \\
\text { manufacturing, telecommunications, pharmaceuticals and electronics, as established by SIC code (Albring et al., 2007; } \\
\text { Muzatko et al., 2004). }\end{array}$ \\
\hline IPO momentum & $\begin{array}{l}\text { Indicators of market momentum during the time leading up to the IPO, including average pre-IPO market returns (Dow and } \\
\text { Martens, 2007), pre-IPO market volatility (Hill and Wilson, 2006) and a variable capturing larger than average new issues in } \\
\text { the pre-IPO period (Filatotchev and Bishop, 2002). }\end{array}$ \\
\hline Firm age & Time since founding, typically in years (Arthurs et al., 2008). \\
\hline Firm size & Total assets (Arthurs et al., 2008; Kor et al., 2008), or total sales at IPO (Certo et al., 2001). \\
\hline Leverage & $\begin{array}{l}\text { Typically long-term debt over total assets (Givoly and Shi, 2007; Petersen, 2007) or total liabilities over total assets (Li and } \\
\text { McConomy, 2004). }\end{array}$ \\
\hline Pre-issue performance & $\begin{array}{l}\text { Typical accounting-type performance measures prior to IPO issue, which include ROA (Arthurs et al., 2008), ROE (Abidin et al., } \\
\text { 2012), sales to book value (Espenlaub and Tonks, 1998), sales growth (Kroll et al., 2007) and net income (Florin and Simsek, } \\
\text { 2007; Fohlin, 2000). Typically measured in the fiscal year prior to the IPO date. }\end{array}$ \\
\hline CEO founder & A dummy variable capturing whether or not the CEO is also the (co-)founder of the company (Certo et al., 2001). \\
\hline Board independence & $\begin{array}{l}\text { Operationalized either as the proportion of insiders on the board of directors (Certo et al., 2001; reverse coded), number of } \\
\text { outside directors (Carpenter et al., 2003) or proportion of outside directors (Beatty and Zajac, 1994). }\end{array}$ \\
\hline Retained ownership & $\begin{array}{l}\text { Includes percentage of equity retained by pre-IPO owners (Certo et al., 2001), the Downes and Henkel (1982) retained } \\
\text { ownership measure (Li and McConomy, 2004), cumulative retained inside ownership (Petersen, 2007), director sell-off or } \\
\text { percentage of shares officers and directors will sell off on the first day of trading (Arthurs et al., 2008; reverse coded). }\end{array}$ \\
\hline Institutional ownership & The percentage of institutional ownership of the firm's stock prior to going public (Kiymaz, 2000). \\
\hline Underwriter reputation & $\begin{array}{l}\text { Various measures of underwriter prestige, including market share (Arthurs et al., 2008; Certo et al., 2001), underwriter fee to } \\
\text { float an issue (Arthurs et al., 2008), position in underwriter ranking, measured both as an indicator and as a continuous } \\
\text { variable (Bubna and Prabhala, 2007; Dow and Martens, 2007), number of successful IPOs completed (Florin and Simsek, 2007) } \\
\text { and frequency of offerings (van der Zahn et al., 2007). }\end{array}$ \\
\hline Auditor reputation & $\begin{array}{l}\text { Measures of auditor reputation, including whether or not the auditor is one of the Big Four (Chang et al., 2007), overall quality } \\
\text { (Bozzolan and Ipino, 2007), the fees paid to the auditor (Chang et al., 2007) and market share (Reber et al., 2005). }\end{array}$ \\
\hline VC-backed & Measures of whether or not the IPO had venture capital backing (Chang et al., 2007; Givoly and Shi, 2007). \\
\hline IPO underpricing & $\begin{array}{l}\text { Most often calculated as the first-day closing price minus the offer price, divided by the offer price (Certo et al., 2001; } \\
\text { Filatotchev and Bishop, 2002). }\end{array}$ \\
\hline IPO proceeds & $\begin{array}{l}\text { Amount of equity capital raised by the firm during the IPO process. Calculated as the product of the offer price and the number } \\
\text { of new shares sold in the offering (Carter et al., 1998). }\end{array}$ \\
\hline Long-term firm risk & $\begin{array}{l}\text { Typically calculated as the standard deviation of returns for each firm post-IPO (Carter et al., 1998). This measure captures } \\
\text { total firm risk, incorporating both market (or systematic) risk and firm-specific (or unsystematic) risk. }\end{array}$ \\
\hline Long-term firm performance & $\begin{array}{l}\text { Both accounting (ROE, ROA, ROS, sales growth, profit) and market (stock performance, Tobin's Q, market to book ratio) } \\
\text { measures of post-IPO performance (Cyr et al., 2000; Kroll et al., 2007; Welbourne and Andrews, 1996). Long-term performance } \\
\text { is measured at least six months after the IPO in the studies included in our analyses. }\end{array}$ \\
\hline
\end{tabular}

(2012), we expect the effect of publication bias to be limited in our case. Specifically, many of the effect sizes we coded do not represent the theoretical focus of the papers they are retrieved from. The antecedents we are interested in were often included as control variables, not as independent variables. As a result, we do not expect that effect sizes that contradict current research were systematically deleted from our sample. Table 2 provides a description of the variables we harvested from these studies. One author coded all effect sizes. To assess inter-rater agreement, a second rater coded a subsample of 200 randomly selected effect sizes, after which we computed a chance-agreement-corrected measure of inter-rater reliability (Cohen's kappa coefficient; Cohen, 1960). With a value of 0.94 , the coefficient signals high inter-rater agreement.

\section{MASEM procedure}

We used meta-analytical structural equation modeling (MASEM; Bergh et al., 2014; Cheung and Chan, 2005) to test Hypotheses 1a through 3d. MASEM employs structural equation modeling on a meta-analytic correlation matrix (Cheung and Chan, 2005). It has three advantages over more conventional bivariate meta-analytic techniques. First, not all relationships specified by the theory under investigation need be included in each primary study, as each cell in the data matrix represents an independent accumulation of the research of primary studies. Second, MASEM allows for the testing of hypotheses that have not yet been tested in prior research, especially those connecting previously unlinked streams of literature (Bergh et al., 2016). Third, MASEM avoids biased estimates when there are possible simultaneity effects at play, and when there is the risk of collinearity between independent variables (Geyskens et al., 2009).

MASEM involves a two-stage procedure (Carney et al., 2011). First, Hedges and Olkin-type meta-analysis (HOMA; Hedges and Olkin, 1985) is used to compute the meta-analytic mean associations between all independent and dependent variables, based on Pearson product-moment correlations $(r)$. This produces the meta-analytic correlation matrix. We used the more conservative random-effects HOMA model, as the meta-analytic community currently favors this model over fixed-effects routines (Geyskens et al., 
2009). We apply the Fisher's $Z r$ transformation to the data, to bring the effect size distribution closer to a normal distribution (Hedges and Olkin, 1985). ${ }^{1}$ In the second stage, the meta-analytic correlation matrix is treated as the observed correlation matrix, and full information maximum likelihood structural equation modeling routines are used to test hypotheses (Cheung and Chan, 2005). To deal with sample size differences across the correlation coefficients included in our matrix, we based our analysis on the harmonic mean sample size $(N=1497)$. The harmonic mean is less sensitive to outliers than the arithmetic mean, making it easier to estimate correct and conservative $t$-values for the model parameters (Geyskens et al., 2006). The data were analyzed using LISREL 8.80 software.

\section{Results}

Table 3 contains the meta-analytic correlation table. Next to the meta-analytic mean for each relationship, Table 3 also contains the total number of primary observations $(N)$ and the aggregate number of samples represented in each cell $(k)$. Table 4 shows the results of our MASEM analysis, both in terms of parameter estimates and overall fit statistics. Overall, the theoretical model fits the data well. The Chi-squared statistic is low for a model of this complexity (747.49), and the generalized fit index (0.95) and root-meansquared residual (0.04) are satisfactory in comparison with conventional cut-off points.

\section{Information asymmetries, underpricing and proceeds}

We found partial support for Hypothesis 1a, which posited that signals reducing information asymmetries between issuers and investors curtail underpricing. Two indicators, firm age and firm leverage, were negatively related to underpricing, whereas involvement in the high-tech industry had a positive relationship, in line with Hypothesis 1a. Three further indicators, firm size, preissue performance, and pre-issue uncertainty, yielded non-significant effects. Board independence had a positive, significant, and counter-hypothesized effect. This finding is consistent with that of Beatty and Zajac (1994), who found that outsider-dominated boards signal high monitoring needs and thus greater uncertainty. We also found partial support for Hypothesis $1 \mathrm{~b}$, which predicted that signals reducing information asymmetries enlarge proceeds. Two indicators, firm size and pre-issue performance, were positively related to IPO proceeds, lending support to Hypothesis 1b. Four other indicators, firm age, firm leverage, pre-issue uncertainty, and involvement in the high-tech industry, yielded non-significant effects. We again found a counter-hypothesized result for board independence, in line with Filatotchev and Bishop's (2002) finding that firms with diverse board structures strive for wealth retention during the IPO.

\section{Stakeholders and temporal orientation}

Hypothesis 2a stated that the involvement of stakeholders with a short-term orientation (reputable underwriters, auditors, and venture capitalists) would lead to lower levels of underpricing, largely due to their interest in maximizing short-term gains, and to their signaling role to outside investors. To our surprise, the involvement of these parties had no effect whatsoever on underpricing, attesting to the need to complement signaling models with a stakeholder-centric theoretical lens.

We found strong support for Hypothesis $2 \mathrm{~b}$. The involvement of reputable underwriters, auditors, and venture capitalists helps enlarge IPO proceeds. Enlarging proceeds thus seems to matter more to short-term stakeholders than pricing accuracy, since this helps auditors and underwriters secure their reputation and provides venture capitalists with a viable exit option. Although we did not find strong support for Hypotheses $2 \mathrm{c}$ and $2 \mathrm{~d}$, we did find significant effects for CEO founders. The presence of a founder CEO increases underpricing, as predicted by Hypothesis 2c. These individuals can afford to send a costly signal about the true quality of the venture by underpricing the offer, as they expect to recoup their losses through a seasoned offering strategy. We also found a significant counter-hypothesized result for the relationship between CEO founders and proceeds, suggesting that the IPO represents also an opportunity for founders to diversify their wealth (McConaughy et al., 1995), in addition to being a vehicle for realizing new projects that would be impossible to fund otherwise (Welbourne and Cyr, 1999). We found a significant counter-hypothesized result pertaining to the relationship between institutional investors and underpricing, implying that their involvement in IPO firms sends a strong quality signal, perhaps unwittingly. In line with our predictions for the behavior of 'dedicated' investors (Bushee, 2001), we found that institutional investors reduce proceeds.

\section{IPO outcomes}

Hypothesis 3a, predicting that IPO underpricing would be positively related to long-term firm performance, was strongly supported by our MASEM results. Underpricing thus serves as an effective signal—one that is highly visible, costly, and difficult to replicate-that provides an indication of the quality of IPO firms (Allan and Faulhaber, 1989; Welch, 1989; Grinblatt and Hwang, 1989). Underpricing comes at a cost, however. In line with Hypothesis 3b, we found underpricing to be positively related to longterm firm risk. This suggests that firms engage in riskier behavior to compensate for the money left on the table by underpricing shares during the IPO. Hypothesis 3c, which proposed a positive relationship between IPO proceeds and long-term firm performance, was also supported. Because greater proceeds lower the cost of capital (Leone et al., 2007), and finance more projects with a positive

\footnotetext{
${ }^{1}$ Fisher's Zr transformed correlations are calculated as follows: $Z_{r}=\frac{1}{2} \ln \left(\frac{1+r}{1-r}\right)$, where $r$ is the untransformed correlation coefficient.
} 


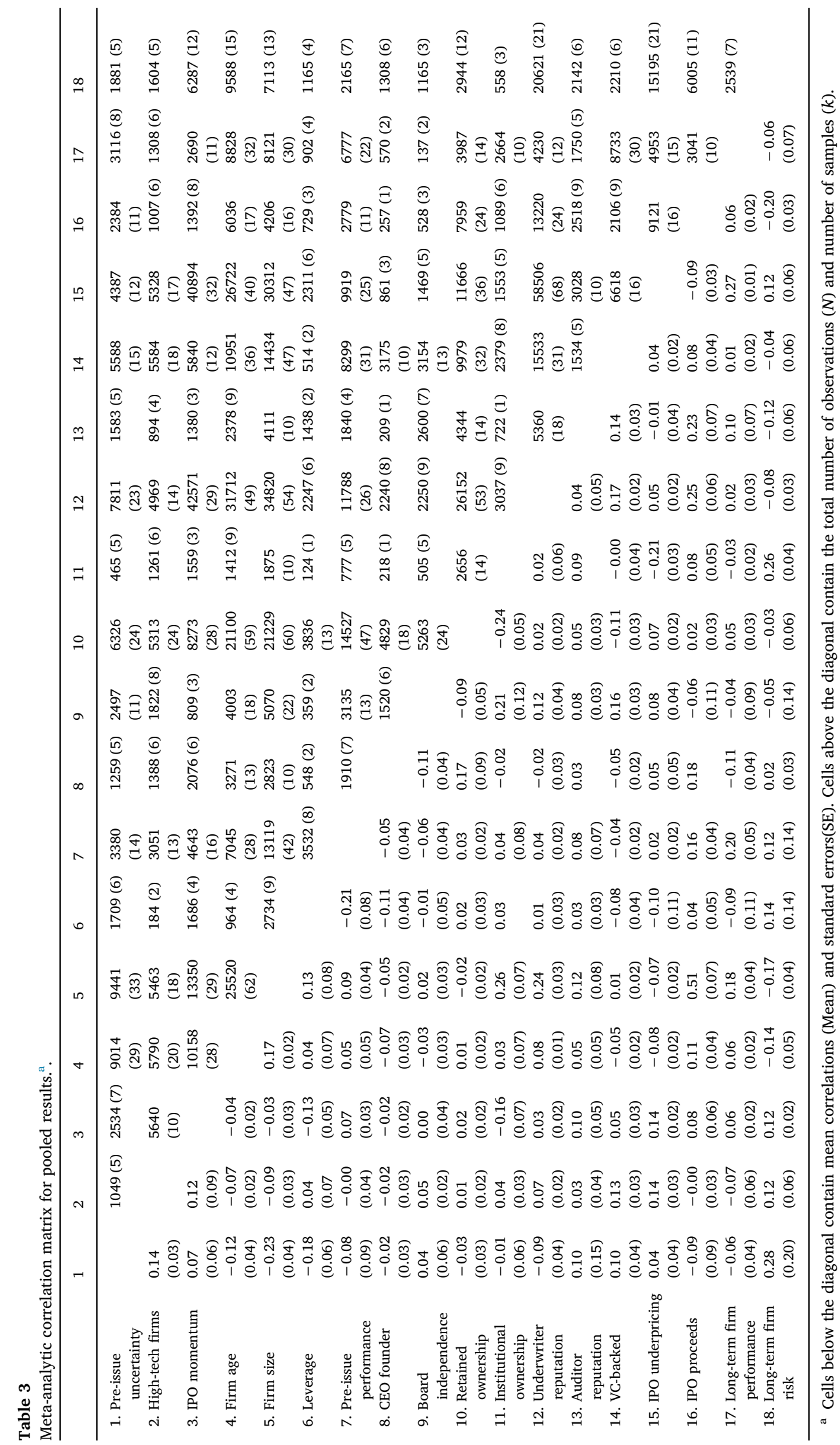


Table 4

MASEM results. ${ }^{\text {a }}$

\begin{tabular}{|c|c|c|c|c|}
\hline Predictors & Underpricing & IPO proceeds & Long-term firm performance & Long-term firm risk \\
\hline Firm age & $-0.06(0.03)(-2.24)^{\mathrm{c}}$ & $0.03(0.02)(1.40)$ & & \\
\hline Firm size & $0.02(0.03)(0.55)$ & $0.48(0.02)(20.50)^{\mathrm{e}}$ & & \\
\hline Firm leverage & $-0.08(0.03)(-2.99)^{\mathrm{d}}$ & $0.04(0.02)(1.71)^{\mathrm{b}}$ & & \\
\hline Pre-issue firm performance & $0.02(0.03)(0.66)$ & $0.12(0.02)(5.39)^{\mathrm{e}}$ & & \\
\hline Board independence & $0.12(0.03)(4.78)^{\mathrm{e}}$ & $-0.07(0.02)(-3.15)^{\mathrm{d}}$ & & \\
\hline Pre-issue uncertainty & $-0.00(0.03)(0.05)$ & $0.03(0.02)(1.31)$ & & \\
\hline High-tech firm & $0.14(0.03)(5.26)^{\mathrm{e}}$ & $0.02(0.02)(1.00)$ & & \\
\hline VC-backed & $-0.01(0.03)(-0.35)$ & $0.05(0.02)(2.38)^{\mathrm{c}}$ & & \\
\hline Underwriter reputation & $0.03(0.03)(1.20)$ & $0.13(0.02)(5.84)^{\mathrm{e}}$ & & \\
\hline Auditor reputation & $-0.01(0.03)(-0.45)$ & $0.14(0.02)(6.67)^{e}$ & & \\
\hline Retained ownership & $0.02(0.03)(0.64)$ & $-0.03(0.02)(-1.54)$ & & \\
\hline CEO founder & $0.05(0.03)(1.95)^{\mathrm{b}}$ & $0.22(0.02)(10.13)^{\mathrm{e}}$ & & \\
\hline Institutional ownership & $-0.22(0.03)(-8.14)^{\mathrm{e}}$ & $-0.05(0.02)(-1.97)^{c}$ & & \\
\hline IPO momentum & $0.08(0.03)(2.96)^{\mathrm{d}}$ & $0.06(0.02)(3.02)^{\mathrm{d}}$ & & \\
\hline Underpricing & & & $0.28(0.02)(11.13)^{\mathrm{e}}$ & $0.10(0.02)(4.06)^{\mathrm{e}}$ \\
\hline IPO proceeds & & & $0.08(0.02)(3.41)^{\mathrm{e}}$ & $-0.19(0.02)(-7.53)^{\mathrm{e}}$ \\
\hline Harmonic mean $N$ & 1493 & & & \\
\hline Chi-square & 747.49 & & & \\
\hline GFI & 0.95 & & & \\
\hline RMSR & 0.048 & & & \\
\hline
\end{tabular}

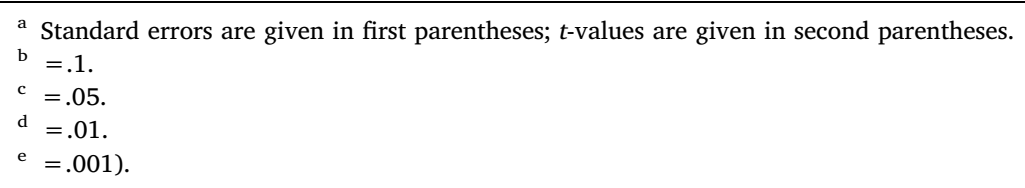

net present value (Welbourne and Cyr, 1999), they have a positive effect on long-term performance. Finally, Hypothesis 3d, which posited that IPO proceeds are negatively related to risk-taking, was also supported by our analysis. An influx of financial resources reduces default risk by restructuring current debt obligations (Pagano et al., 1998), allows firms to attract outside resources on better terms, and builds up a buffer of slack resources capable of resisting exogenous shocks.

\section{Additional analyses}

We performed two additional analyses to establish the robustness of our results. First, we conducted additional HOMA analyses to establish whether variation in measures of long-term performance was driving our results. Specifically, we distinguished between long-term accounting measures for performance, such as ROA and ROE, and long-term market measures for performance, such as Tobin's Q and market-to-book ratio. In our sample, $46 \%$ of studies used accounting-based performance measures, whereas $54 \%$ use market-based ones. We found no evidence of a moderating effect of the performance variable choice on the relationship between IPO proceeds and long-term performance (accounting performance: mean $r=0.05, k=8$; market performance: mean $r=0.08, k=2$ ). However, we detected a highly significant moderating effect on the relationship between IPO underpricing and long-term performance (accounting performance: mean $r=-0.03$ (n.s.), $k=8$; market performance: mean $r=0.37, k=7$ ). This implies that when issuers engage in underpricing, they tend to face a long-term struggle to restore their accounting profitability.

Second, we explored whether or not the fact that the majority of our effect sizes (70\%) stem from the U.S. context had a moderating effect on our findings. We conducted two additional meta-analytic regression analyses (MARA; Lipsey and Wilson, 2001), in which effect sizes linking antecedent variables to underpricing and proceeds respectively were regressed on a vector of potentially moderating variables, including the U.S. or non-U.S. origin of each effect size. ${ }^{2}$ The U.S. dummy variable turned out not to be significant in either model, suggesting that the U.S. effect sizes were not driving our overall results.

\footnotetext{
${ }^{2}$ Both regression tables can be obtained from the authors upon request.
} 


\section{Discussion}

\section{Antecedents of short-term performance in IPO firms}

Our study blends insights from two theories, namely signaling theory (Connelly et al., 2010; Daily et al., 2003) and stakeholder theory (Freeman, 1984; Frooman, 1999) to develop a new perspective on the drivers of short-term IPO firm performance (Hypotheses 1 a to 2 d). Our findings suggest that both theoretical lenses offer complementary explanations.

Our most important extension of signaling models in IPO research (Certo et al., 2009; Daily et al., 2003; Ibbotson et al., 1988) is that, in addition to underpricing, we also investigate the effects of antecedent variables on proceeds. Our findings show that underpricing and proceeds capture different dimensions of short-term IPO outcomes, and are explained by different antecedents (Gulati and Higgins, 2003). In terms of fine-grained results, we found that firm age, leverage, and belonging to a non-high technology industry reduce underpricing, while firm size and pre-issue performance enlarge proceeds. We also found counter-hypothesized effects for board independence. Firms with independent boards not only underprice their shares more, but also raise fewer proceeds. Beatty and Zajac (1994) attribute this to the fact that independent boards signal higher monitoring needs, and thus the presence of greater uncertainty. Since proceeds form a separate dimension of short-term IPO outcomes, we recommend that researchers adopt a wider, multidimensional view on short-term IPO outcomes. Overall, however, we found few statistically significant effects, and even fewer materially significant ones, as the overall effect sizes we retrieved were small. We therefore conclude that signaling models are limited in their ability to predict short-term IPO performance, which suggests that IPO researchers need to broaden their conceptual scope beyond the theoretical lenses that are currently popular (Certo et al., 2009).

We diverged from signaling models by assessing the role of stakeholders in influencing short-term IPO outcomes. To capture the multi-stakeholder nature of the IPO process, we differentiated between stakeholders with short- and long-term orientations (Arthur et al., 2008; Jia and Zhang, 2014). For short-term stakeholders, the evidence is strong but results are mixed. Contrary to what we posited in Hypothesis 2a, we found no significant effect of parties like venture capitalists, underwriters, and auditors on underpricing. Apparently, the dual agency of underwriters (issuers versus institutional investors), venture capitalists (issuers versus owners of the venture capital firm), and auditors (issuers versus prospective clients) (Arthur et al., 2008) leads these short-term-oriented stakeholders to adopt a balanced position on the issue of underpricing. Particularly in the case of venture capitalists, a recent meta-analysis suggests that these investors may not add as much value to the firms they are involved in as previously thought (Rosenbusch, Brinckmann, Müller, 2013). Interestingly, and consistent with our reasoning for Hypothesis 2b, the involvement of any stakeholder with a short-term orientation increases IPO proceeds. In terms of stakeholders with a long-term orientation, we found that only CEO founders act in accordance with the theory that underpins Hypothesis 2c. Founders seek to increase underpricing because of its signal value, as they are more concerned with the firm's long-term performance than with short-term gains. However, we did not find these effects for institutional investors and inside owners.

\section{Antecedents of long-term firm performance and long-term firm risk}

We made an attempt to disentangle the relationship between short- and long-term IPO outcomes. A better understanding of this relationship is critical, as IPO firms have been documented to under perform the wider stock market in the long run (Ritter and Welch, 2002). Our findings support our contention that underpricing and IPO proceeds are driven by different mechanisms and have different effects on long-term outcomes. On average, underpricing has a positive effect on long-term firm performance. While underpricing is arguably the equivalent of "throwing money away" (Daily et al., 2003: 287), most firms are able to make good on these losses at a later point in time. Yet conveying firm quality through underpricing is a costly signal in many ways. Issuers of underpriced equity not only struggle to regain profitability until long after the IPO, but they also face greater long-term firm risk. The relatively confined period of the IPO process thus leaves a lasting mark on firms' behavior and performance. IPO proceeds also have a positive effect on long-term firm performance. Even when controlling for prior financial performance and firm size, firms that raise greater IPO proceeds outperform firms with smaller proceeds. As predicted, greater IPO proceeds are associated with lower long-term firm risk, as a large influx of financial capital reduces default risk, allows firms to access outside resources on more advantageous terms, and protects them against exogenous shocks.

\section{Theoretical implications}

Our study has several theoretical implications. First, signals of quality are not universally beneficial. While such signals do influence the IPO process, their suitability depends on the desired outcome. Some signals reduce underpricing, but do not necessarily support IPO firms in enlarging proceeds (for instance, firm age), while others help to increase proceeds, while not assisting IPO firms to reduce underpricing (for instance, firm size).

Second, signaling models cannot fully explain the influence various stakeholder groups have on short-term IPO outcomes. Different stakeholders are driven by different motivations, and push for different outcomes, especially with respect to proceeds. Furthermore, outside investors may be more sophisticated in terms of how they interpret signals from IPO firm stakeholders than what is commonly assumed (Daily et al., 2003). For instance, they attribute more weight to the signals sent by CEO founders than to those emitted by reputable underwriters, whose involvement is considered limited to the IPO period. We thus believe that stakeholder theory can significantly advance our understanding of the IPO process.

Third, there are trade-offs between short- and long-term outcomes for IPO firms, some of which may be unintended. When IPO 
firms engage in excessive underpricing, they induce investors to sink their capital into a relatively risky and potentially unprofitable venture. When buying an issuer's shares at a large discount, investors must realize that they are becoming partial owners of a firm that will have engage in significant risk-taking in the future as a consequence of its decision to underprice. The firm will struggle to remain profitable because of the unfavorable cost of its capital. It may similarly seem that pursuing higher IPO proceeds is a 'cost-free' option for IPO firms. However, when stakeholders are added back into the equation, an obvious trade-off becomes apparent. Firm insiders have limited influence over firm valuation, which is subject to the perceptions of underwriters, auditors, and institutional investors (Jenkinson and Jones, 2009). It follows that firms' existing shareholders have to trade off higher retained equity against the possibility of raising more proceeds during the IPO.

\section{Limitations and future research}

Our study made a first attempt at integrating stakeholders' interests into our understanding of the IPO process. However, more research is needed to develop the proposed stakeholder-centric perspective. In particular, we encourage researchers to explore other aspects of stakeholder involvement, beyond temporal orientation. Characteristics of stakeholders that we think hold promise are stakeholder salience (Mitchell et al., 1997), stakeholder influence strategies (Frooman, 1999), and stakeholder relevance in light of the focal firm's life cycle stage (Jawahar and McLaughlin, 2001). We also advocate for a dynamic approach that incorporates the stakeholders' real behavior post-IPO. Our paper examines the role of stakeholders in shaping short-term outcomes, but there is still much to understand regarding how pre-IPO stakeholders behave post-IPO and influence long-term outcomes.

More research is needed to fully understand the trade-offs IPO firms are required to make between short-term and long-term performance (McMullen and Shepherd, 2006). Our study highlights the negative consequences of underpricing over the longer term (such as increasing firm risk), but does not investigate the conditions under which this negative outcome can be reduced. As high underpricing is not always avoidable for IPO firms, future research is needed to explore how they can navigate the pitfalls associated with underpricing and keep long-term risk at controllable levels. Future research can help advance our understanding of the IPO process, by investigating how IPO short-term outcomes affect strategic behaviors in the future, including risk-bearing investments in research and development or internationalization. While there is still much to learn about firms going public, the present study has made a first attempt at delving into the long-term effects of the IPO process on subsequent strategic behavior.

\section{Conclusion}

Our paper has integrated insights from signaling theory and stakeholder theory to further our understanding of the IPO process. Three theoretical insights emerge from this integration. First, the suitability of quality signals depends greatly on the short-term outcome under consideration. Signals that help reduce underpricing may not help to enlarge proceeds, and vice versa. Second, while signaling theory has merit in terms of explaining short-term IPO outcomes, it does not portray a full picture of the IPO phenomenon, as it does not account for the multi-stakeholder nature of the IPO process. Our study specifically highlights the role of the temporal orientation of stakeholders in shaping their interests regarding short-term IPO outcomes. Third, underpricing and proceeds continue to shape firm behaviors long after the IPO, often leading to trade-offs between short- and long-term outcomes. Underpricing positively affects long-term firm performance, but at the expense of heightening long-term firm risk. Proceeds appear generally beneficial, in the sense that they reduce long-term firm risk and enhance long-term firm performance. Nonetheless, from the perspective of firm insiders, larger proceeds imply surrendering more control by offering a larger equity share in the firm to new public investors.

\section{Appendix A. Supplementary data}

Supplementary data related to this article can be found at https://doi.org/10.1016/j.lrp.2018.10.003.

\section{References}

Akerlof, G.A., 1970. The market for 'lemons': qualitative uncertainty and the market mechanism. Q. J. Econ. 84 (3), $488-500$.

Alavi, A., Pham, P., Pham, T., 2008. Pre-IPO ownership structure and its impact on the IPO process. J. Bank. Finance 32 (11), $2361-2375$.

Allen, F., Faulhaber, G.R., 1989. Signaling by underpricing in the IPO market. J. Financ. Econ. 23 (2), $303-323$.

Alvarez, S.A., Busenitz, L.W., 2001. The entrepreneurship of resource-based theory. J. Manag. 27 (6), $755-775$.

Arikan, A.M., Capron, L., 2010. Do newly public acquirers benefit or suffer from their pre-IPO affiliations with underwriters and VCs? Strat. Manag. J. 31 (12), $1257-1289$.

Autore, D.M., Bray, D.E., Peterson, D.R., 2009. Intended use of proceeds and the long-run performance of seasoned equity issuers. J. Corp. Finance 15, 358-367.

Barry, C.B., Mihov, V.T., 2006. Debt financing, venture capital, and initial public offerings. Work. Pap.

Bascha, A., Walz, U., 2001. Convertible securities and optimal exit decision in venture capital finance. J. Corp. Finance 7 (3), $285-306$.

Beatty, R.P., 1989. Auditor reputation and the pricing of initial public offerings. Account. Rev. 693-709.

Beatty, R.P., Ritter, J.R., 1986. Investment banking, reputation, and the underpricing of initial public offerings. J. Financ. Econ. 15 (1), $213-232$.

Beatty, R.P., Welch, I., 1996. Issuer expenses and legal liability in initial public offerings. J. Law Econ. 39, 545-602.

Benveniste, L.M., Spindt, P.A., 1989. How investment bankers determine the offer price and allocation of new issues. J. Financ. Econ. 24, 343-361.

Bergh, D.D., Aguinis, H., Heavey, C., Ketchen, D.J., Boyd, B.K., Su, P., Joo, H., 2016. Using meta-analytic structural equation modeling to advance strategic management research: guidelines and an empirical illustration via the strategic leadership-performance relationship. Strat. Manag. J. 37 (3), $477-497$.

Bergh, D.D., Connelly, B.L., Ketchen, D.J., Shannon, L.M., 2014. Signalling theory and equilibrium in strategic management research: an assessment and a research agenda. J. Manag. Stud. 51 (8), 1334-1360.

Berger, A.N., Udell, G.F., 1998. The economics of small business finance: the roles of private equity and debt markets in the financial growth cycle. J. Bank. Finance 22 (6-8), 613-673. 
Bethel, J.E., Liebeskind, J., 1993. The effects of ownership structure on corporate restructuring. Strat. Manag. J. 14, 15-31.

Bondt, W.F., Thaler, R., 1985. Does the stock market overreact? J. Finance 40 (3) 7930-805.

Bruton, G.D., Filatotchev, I., Chahine, S., Wright, M., 2010. Governance, ownership structure, and performance of IPO firms: the impact of different types of private equity investors and institutional environments. Strat. Manag. J. 31 (5), 491-509.

Bushee, B.J., 2001. Do institutional investors prefer near-term earnings overlong-run value? Contemp. Account. Res. 18 (2), $207-246$.

Carter, R., Manaster, S., 1990. Initial public offerings and underwriter reputation. J. Finance 45 (4), 1045-1067.

Certo, S.T., Daily, C.M., Dalton, D.R., 2001b. Signaling firm value through board structure: an investigation of initial public offerings. Enterpren. Theor. Pract. 26 (2), $33-50$.

Certo, S.T., Holcomb, T.R., Holmes, R.M., 2009. IPO research in management and entrepreneurship: moving the research agenda forward. J. Manag. 35 (6), 1340-1378.

Chan, K., Wang, J., Wei, K.J., 2004. Underpricing and long-term performance of IPOs in China. J. Corp. Finance 10 (3), $409-430$.

Chen, H., Ritter, J., 2000. The seven percent solution. J. Finance 55, 1105-1131.

Cheung, M.W.L., Chan, W., 2005. Meta-analytic structural equation modeling: a two-stage approach. Psychol. Methods 10 (1), 40.

Cohen, B.D., Dean, T.J., 2005. Information asymmetry and investor valuation of IPOs: top management team legitimacy as a capital market signal. Strat. Manag. J. 26 (7), 683-690.

Cohen, J., 1960. A coefficient of agreement for nominal scales. Educ. Psychol. Meas. 20 (1), 37-46.

Connelly, B.L., Certo, S.T., Ireland, R.D., Reutzel, C.R., 2011. Signaling theory: a review and assessment. J. Manag. 37 (1), $39-67$.

Connelly, B.L., Hoskisson, R.E., Tihanyi, L., Certo, S.T., 2010. Ownership as a form of corporate governance. J. Manag. Stud. 47 (8), $1561-1589$.

Cooper, H., 1998. Synthesizing Research: a Guide for Literature Reviews. Sage, Thousand Oaks, CA.

Corwin, S.A., Schultz, P., 2005. The role of IPO underwriting syndicates: pricing, information production, and underwriter competition. J. Finance 60 (1), 443-486. Cumming, D., Johan, S., 2010. Venture capital investment duration. J. Small Bus. Manag. 48 (2), 228-257.

Cumming, D.J., MacIntosh, J.G., 2003. A cross-country comparison of full and partial venture capital exits. J. Bank. Finance 27 (3), $511-548$.

Daily, C.M., Certo, S.T., Dalton, D.R., Roengpitya, R., 2003. IPO underpricing: a meta-analysis and research synthesis. Enterpren. Theor. Pract. 27 (3), $271-295$.

Dalton, D.R., Aguinis, H., Dalton, C.M., Bosco, F.A., Pierce, C.A., 2012. Revisiting the file drawer problem in meta-analysis: an Assessment of published and nonpublished correlation matrices. Person. Psychol. 65 (2), 221-249.

Dalziel, T., White, R.E., Arthurs, J.D., 2011. Principal costs in initial public offerings. J. Manag. Stud. 48 (6), $1346-1364$.

Deeds, D.L., Decarolis, D., Coombs, J.E., 1997. The impact of firm specific capabilities on the amount of capital raised in an initial public offering: evidence from the biotechnology industry. J. Bus. Ventur. 12 (1), 31-46.

Delmar, F., Davidsson, P., Gartner, W.B., 2003. Arriving at the high-growth firm. J. Bus. Ventur. 18 (2), $189-216$.

Draho, J., 2004. The IPO Decision: Why and How Companies Go Public. Edward Elgar Publishing.

Engelen, P.J., 2003. Underpricing of IPOs: belgian evidence. European Review of Economics and Finance 2, 53-69.

Engelen, P.J., van Essen, M., 2010. Underpricing of IPOs: firm-, issue-and country-specific characteristics. J. Bank. Finance 34 (8), $1958-1969$.

EY, 2013. EY's Guide to Going Public. Retrieved at. https://www.ey.com/gl/en/services/strategic-growth-markets/ey-guide-to-going-public.

Ferris, S.P., Hiller, J.S., Wolfe, G.A., Cooperman, E.S., 1992. An analysis and recommendation for prestigious underwriter participation in IPOs. J. Corp. Law 581-603. Field, L.C., Hanka, G., 2001. The expiration of IPO share lockups. J. Finance 56 (2), 471-500.

Freeman, J., Carroll, G.R., Hannan, M.T., 1983. The liability of newness: age dependence in organizational death rates. American Sociology Review 95, 426-439. Freeman, R.E., 1984. Strategic Management: a Stakeholder Approach. Pitman Publishing, Boston, MA.

Frooman, J., 1999. Stakeholder influence strategies. Acad. Manag. Rev. 24 (2), 191-205.

George, G., 2005. Slack resources and the performance of privately held firms. Acad. Manag. J. 48 (4), $661-676$.

Geyskens, I., Steenkamp, J.B.E., Kumar, N., 2006. Make, buy, or ally: a transaction cost theory meta-analysis. Acad. Manag. J. 49 (3), $519-543$.

Geyskens, I., Krishnan, R., Steenkamp, J.B.E., Cunha, P.V., 2009. A review and evaluation of meta-analysis practices in management research. J. Manag. 35 (2),

393-419.

Gilbert, B.A., McDougall, P.P., Audretsch, D.B., 2006. New venture growth: a review and extension. J. Manag. 32 (6), $926-950$.

Giot, P., Schwienbacher, A., 2007. IPOs, trade sales and liquidations: modelling venture capital exits using survival analysis. J. Bank. Finance 31 (3), 679-702.

Gompers, P., 1995. Optimal investment, monitoring, and the staging of venture capital. J. Finance 50, 1461-1489.

Gordon, M.J., Jin, J., 1993. Risk, asymmetric payoffs, and the underpricing of initial public offerings. Res. Finance 11, $133-165$.

Gorman, M., Sahlman, W.A., 1989. What do venture capitalists do? J. Bus. Ventur. 4 (4), 231-248.

Grinblatt, M., Hwang, C.Y., 1989. Signaling and the pricing of unseasoned new issues. J. Finance 44 (2), $393-420$.

Hedges, L.V., Olkin, I., 1985. Statistical Methods for Meta-analysis. Academic Press, Orlando, FL.

Holcomb, T.R., Combs, J.G., Sirmon, D.G., Sexton, J., 2010. Modeling levels and time in entrepreneurship research: an illustration with growth strategies and post-IPO performance. Organ. Res. Methods 13 (2), 348-389.

Ibbotson, R.G., Sindelar, J.L., Ritter, J.R., 1988. Initial public offerings. Bank Am. J. Appl. Corp. Finance 1 (2), $37-45$.

James, C., Wier, P., 1990. Borrowing relationships, intermediation, and the cost of issuing public securities. J. Financ. Econ. 28 (1), $149-171$.

Jawahar, I.M., McLaughlin, G.L., 2001. Toward a descriptive stakeholder theory: an organizational life cycle approach. Acad. Manag. Rev. 26 (3), $397-414$.

Jegadeesh, N., Weinstein, M., Welch, I., 1993. An empirical investigation of IPO returns and subsequent equity offerings. J. Financ. Econ. 34 (2), $153-175$.

Jenkinson, T., Jones, H., 2009. IPO pricing and allocation: a survey of the views of institutional investors. Rev. Financ. Stud. 22 (4), 1477-1504.

Jia, M., Zhang, Z., 2014. Donating money to get money: the role of corporate philanthropy in stakeholder reactions to IPOs. J. Manag. Stud. 51 (7), $1118-1152$.

Johnson, J.M., Miller, R.E., 1988. Investment banker prestige and the underpricing of initial public offerings. Financ. Manag. 19-29.

Leland, H.E., Pyle, D.H., 1977. Informational asymmetries, financial structure, and financial intermediation. J. Finance 32 (2), $371-387$.

Leone, A.J., Rock, S., Willenborg, M., 2007. Disclosure of intended use of proceeds and underpricing in initial public offerings. J. Account. Res. 45 (1), 111-153.

Li, M., McInish, T.H., Wongchoti, U., 2005. Asymmetric information in the IPO aftermarket. Financ. Rev. 40 (2), $131-153$.

Lipsey, M.W., Wilson, D.B., 2001. Practical Meta-analysis. Sage, Thousand Oaks, CA.

Ljungqvist, A., 2007. IPO underpricing. In: Handbook of Corporate Finance. Empirical Corporate Finance. Elsevier, North-Holland.

Ljungqvist, A.P., Wilhelm, J., 2003. IPO pricing in the dot-com bubble. J. Finance 58 (2), 723-752.

Loughran, T., Ritter, J.R., 2002. Why don't issuers get upset about leaving money on the table in IPOs? Rev. Financ. Stud. 15 (2), $413-444$.

McConaughy, D.L., Dhatt, M.S., Kim, Y.H., 1995. Agency costs, market discipline and market timing: evidence from post-IPO operating performance. Enterpren. Theor. Pract. 20, 43-58.

McMullen, J.S., Shepherd, D.A., 2006. Entrepreneurial action and the role of uncertainty in the theory of the entrepreneur. Acad. Manag. Rev. 31 (1), 132-152.

Megginson, W., Weiss, K., 1991. Venture capitalist certification in initial public offerings. J. Finance 46 (3), $879-903$.

Meglio, O., Destri, A.M.L., Capasso, A., 2017. Fostering dynamic growth in new ventures through venture capital: conceptualizing venture capital capabilities. Long. Range Plan. 50 (4), 518-530.

Mitchell, R.K., Agle, B.R., Wood, D.J., 1997. Toward a theory of stakeholder identification and salience: defining the principle of who and what really counts. Acad. Manag. Rev. 22 (4), 853-886.

Morrow, J.L., Sirmon, D.G., Hitt, M.A., Holcomb, T.R., 2007. Creating value in the face of declining performance: firm strategies and organizational recovery. Strat. Manag. J. 28 (3), 271-283.

Nofsinger, J.R., Wang, W., 2011. Determinants of start-up firm external financing worldwide. J. Bank. Finance 35 (9), $2282-2294$.

Pagano, M., Panetta, F., Zingales, L., 1998. Why do companies go public? An empirical analysis. J. Finance 53 (1), $27-64$.

Pollock, T.G., 2004. The benefits and costs of underwriters' social capital in the US initial public offerings market. Strat. Organ. 2 (4), $357-388$.

Quintana-García, C., Benavides-Velasco, C.A., 2016. Gender diversity in top management teams and innovation capabilities: the initial public offerings of 
biotechnology firms. Long. Range Plan. 49 (4), 507-518.

Ragozzino, R., 2016. Who gets first dibs? A buy-side investigation of the dual tracking phenomenon in M\&A. Long. Range Plan. 49 (2), 207-220.

Ragozzino, R., Shafi, K., Blevins, D.P., 2018. The effects of pre-IPO corporate activity on newly-public firms' growth. Long. Range Plan. 51 (2), $219-233$.

Ravasi, D., Marchisio, G., 2003. Going public and the enrichment of a supportive network. Small Bus. Econ. 21 (4), 381-395.

Ritter, J., 1987. The costs of going public. J. Financ. Econ. 19 (2), 269-281.

Ritter, J.R., 1998. Initial public offerings. Contemporary Finance Digest 2, 5-30.

Ritter, J.R., 2014. Initial public offerings: updated statistics. Work. Pap.

Ritter, J.R., Welch, I., 2002. A review of IPO activity, pricing, and allocations. J. Finance 57 (4), 1795-1828.

Röell, A., 1996. The decision to go public: an overview. Eur. Econ. Rev. 40 (3-5), 1071-1081.

Rosenbusch, N., Brinckmann, J., Müller, V., 2013. Does acquiring venture capital pay off for the funded firms? A meta-analysis on the relationship between venture capital investment and funded firm financial performance. J. Bus. Ventur. 28 (3), 335-353.

Ruud, J.S., 1993. Underwriter price support and the IPO underpricing puzzle. J. Financ. Econ. 34 (2), 135-151.

Schwienbacher, A., 2008. Venture capital investment practices in Europe and the United States. Financ. Mark. Portfolio Manag. 22 (3), $195-217$.

Teoh, S.H., Welch, I., Wong, T.J., 1998. Earnings management and the long-run market performance of initial public offerings. J. Finance 53 (6), $1935-1974$.

Thaler, R.H., 2015. Misbehaving: the Making of Behavioral Economics. WW Norton \& Company.

Tinic, S.M., 1988. Anatomy of initial public offerings of common stock. J. Finance 43 (4), 789-822.

Titman, S., Trueman, B., 1986. Information quality and the valuation of new issues. J. Account. Econ. 8 (2), 159-172.

Tsang, E.W., Blevins, D.P., 2015. A critique of the information asymmetry argument in the management and entrepreneurship underpricing literature. Strat. Organ. 13 (3), 247-258.

Wang, T., Song, M., 2016. Are founder directors detrimental to new ventures at initial public offering? J. Manag. 42 (3), 644-670.

Wang, X.A., Wan, W.P., 2013. Explaining the variance in underpricing among Venture Capital-backed IPOs: a comparison between private and corporate VC firms. Strategic Entrepreneurship Journal 7 (4), 331-342.

Welch, I., 1989. Seasoned offerings, imitation costs and the underpricing of initial public offerings. J. Finance 44 (2), 421-449.

Wiseman, R.M., Bromiley, P., 1996. Toward a model of risk in declining organizations: an empirical examination of risk, performance and decline'. Organ. Sci. 7 (5), 524-543.

Wright, P., Kroll, M., Krug, J.A., Pettus, M., 2007. Influences of top management team incentives on firm risk taking. Strat. Manag. J. 28 (1), $81-89$.

\section{Futher reading}

*Indicates studies that were included in our meta-analysis.

Abbott, J., Parker, S., 2000. Auditor selection and audit committee characteristics. *. Audit J. Pract. Theor. 19 (2), 47-66.

Abdullah, N.A.H., Mohd, K.N.T., 2004. Factors influencing the underpricing of initial public offerings in an emerging market: malaysian evidence. *. IIUM J. Econ. Manag. 12 (2), 1-21.

Abidin, S., Reddy, K., Zhu, Y., 2012. What cause the underpricing of IPOs and the long-run performance of stocks? *. Work. Pap.

Agrawal, A., Cooper, T., 2010. Accounting scandals in IPO firms: do underwriters and VCs help? *. J. Econ. Manag. Strat. 19 (4), $1117-1181$.

Albring, S.M., Elder, R.J., Zhou, J., 2007. IPO underpricing and audit quality differentiation within non-Big 5 firms. *. Int. J. Audit. 11 (2), 115-131.

Allcock, D., Filatotchev, I., 2010. Executive incentive schemes in initial public offerings: the effects of multiple-agency conflicts and corporate governance. *. J.

Manag. 36 (3), 663-686.

Amason, A.C., Shrader, R.C., Tompson, G.H., 2006. Newness and novelty: relating top management team composition to new venture performance. *. J. Bus. Ventur. 21 (1), 125-148.

Andrews, A.O., Welbourne, T.M., 2000. The people/performance balance in IPO firms: the effect of the chief executive officer's financial orientation. *. Enterpren.

Theor. Pract. 25 (1), 93-106.

Arthurs, J.D., Busenitz, L.W., 2006. Dynamic capabilities and venture performance: the effects of venture capitalists. *. J. Bus. Ventur. 21 (2), $195-215$.

Arthurs, J.D., Busenitz, L.W., Hoskisson, R.E., Johnson, R.A., 2009. Signaling and initial public offerings: the use and impact of the lockup period. *. J. Bus. Ventur. 24 (4), 360-372.

Arthurs, J.D., Hoskisson, R.E., Busenitz, L.W., Johnson, R.A., 2008. Managerial agents watching other agents: multiple agency conflicts regarding underpricing in IPO firms. *. Acad. Manag. J. 51 (2), 277-294.

Bae, S.C., Klein, D.P., Bowyer, J.W., 1999. Determinants of underwriter participation in initial public offerings of common stock: an empirical study. *. J. Bus. Finance Account. 26 (5-6), 595-619.

Banerjee, S., Dai, L., Shrestha, K., 2011. Cross-country IPOs: what explains differences in underpricing? *. J. Corp. Finance 17 (5), $1289-1305$.

Beatty, R.P., Zajac, E.J., 1994. Managerial incentives, monitoring, and risk bearing: a study of executive compensation. *. Adm. Sci. Q. 39 (2), $313-335$.

Bell, R.G., Moore, C.B., Al-Shammari, H.A., 2008. Country of origin and foreign IPO legitimacy: Understanding the role of geographic scope and insider ownership. *. Entrepreneurship Theory and Practice 32 (1), 185-202.

Bloodgood, J.M., Sapienza, H.J., Almeida, J.G., 1997. The internationalization of new high-potential U.S. ventures: antecedents and outcomes. *. Enterpren. Theor. Pract. 20, 61-76.

Boone, A.L., Field, L.C., Karpoff, J.M., Raheja, C.G., 2007. The determinants of corporate board size and composition: An empirical analysis. *. Journal of Financial Economics 85 (1), 66-101.

Bozzolan, S., Ipino, E., 2007. Information asymmetries and IPO underpricing: the role of voluntary disclosure of forward-looking information in the prospectus. *. Work. Pap.

Bubna, A., Prabhala, R., 2007. When Bookbuilding Meets IPOs. *. Indian School of Business, Working Paper.

Butler, A.W., Wan, H., 2005. Investment bank compensation and IPO pricing. *. Work. Pap.

Carney, M., Gedajlovic, E.R., Heugens, P.P., Van Essen, M., Van Oosterhout, J.H., 2011. Business group affiliation, performance, context, and strategy: a meta-analysis. *. Acad. Manag. J. 54 (3), 437-460.

Carpenter, M.A., Pollock, T.G., Leary, M.M., 2003. Testing a model of reasoned risk-taking: governance, the experience of principals and agents, and global strategy in high-technology IPO firms. *. Strat. Manag. J. 24 (9), 803-820.

Carcello, J.V., Nagy, A.L., 2002. Auditor industry specialization and fraudulent financial reporting. * In: Symposium on Auditing Problems.

Carcello, J.V., Hermanson, D.R., Neal, T.L., Riley, R.A., 2002. Board characteristics and audit fees. Contemp. Account. Res. 19 (3), $365-384$.

Carter, R.B., Dark, F.H., 1990. The use of the over-allotment option in initial public offerings of equity: risks and underwriter prestige. *. Financ. Manag. 19, 55-64. Carter, R.B., Dark, F.H., Singh, A.K., 1998. Underwriter reputation, initial returns, and the long-run performance of IPO stocks. *. J. Finance 53 (1), 285-311.

Certo, S.T., Covin, J., Daily, C.M., Dalton, D.R., 2001a. Wealth and the effects of founder management among IPO-stage new ventures. *. Strat. Manag. J. 22 (6-7), 641-658.

Certo, S.T., Daily, C.M., Cannella, A.A., Dalton, D.R., 2003. Giving money to get money: how CEO stock options and CEO equity enhance IPO valuations. *. Acad. Manag. J. 46 (5), 643-653.

Chaddad, F.R., Reuer, J.J., 2009. Investment dynamics and financial constraints in IPO firms. *. Strategic Entrepreneurship Journal 3 (1), $29-45$.

Chambers, D., Dimson, E., 2009. IPO underpricing over the very long run. *. J. Finance 64 (3), 1407-1443.

Chang, X., Gygax, A.F., Oon, E., Zhang, H.F., 2007. Audit quality, auditor compensation and IPO underpricing. *. Account. Finance 48, 391-416.

Chen, C.R., Mohan, N., 2002. Underwriter spread, underwriter reputation, and IPO underpricing: a simultaneous equation analysis. *. J. Bus. Finance Account. 29 (3-4), 521-540. 
Chin, C., Lin, H.W., Syu, Y.E., 2011. On the association between IPO underpricing and reversal and Taiwan's regulatory reforms for mandatory forecasts. *. J. Forecast. 30 (2), 225-248.

Chua, L., 1995. A reexamination of the costs of firm commitment and best efforts IPOs. *. Financ. Rev. 30 (2), $337-365$.

Clarkson, P.M., 1994. The underpricing of initial public offerings, ex ante uncertainty, and proxy selection. *. Account. Finance 34 (2), 67-78.

Clarkson, P.M., Dontoh, A., Richardson, G., Sefcik, S.E., 1991. Retained ownership and the valuation of initial public offerings: Canadian evidence. *. Contemp. Account. Res. 8 (1), 115-131.

Cyr, L.A., Johnson, D.E., Welbourne, T.M., 2000. Human resources in initial public offering firms: do venture capitalists make a difference? *. Enterpren. Theor. Pract. 25 (1), 77-91.

Daily, C.M., Certo, S.T., Dalton, D.R., 2005. Investment bankers and IPO pricing: does prospectus information matter? *. J. Bus. Ventur. 20, 93-111.

Daugherty, M.S., Jithendranathan, T., 2012. Underpricing of IPOs of US family controlled businesses. *. J. Finance Econ.

Decarolis, D.M., Deeds, D.L., 1999. The impact of stocks and flows of organizational knowledge on firm performance: an empirical investigation of the biotechnology industry. *. Strat. Manag. J. 20, 953-968.

Deeds, D.L., Decarolis, D., Coombs, J.E., 1998. Firm-specific resources and wealth creation in high-technology ventures: evidence from newly public biotechnology firms. *. Enterpren. Theor. Pract. 55-73.

Dow, S., Martens, M., Toffanin, M., 2007. IPOs in the upside down world of over-valued equity. *. Work. Pap.

Dowling, M.J., McGee, J.E., 1994. Business and technology strategies and new venture performance: a study of the telecommunications equipment industry. *. Manag. Sci. 40 (12), 1663-1677.

Eisenmann, T.R., 2006. Internet companies' growth strategies: determinants of investment intensity and long-term performance. *. Strat. Manag. J. 27 (12), $1183-1204$.

Espenlaub, S., Tonks, I., 1998. Post-IPO directors' sales and reissuing activity: an empirical test of IPO signaling models. *. J. Bus. Finance Account. 25 (9-10), 1037-1079.

Filatotchev, I., Bishop, K., 2002. Board composition, share ownership and underpricing of UK IPO firms. *. Strat. Manag. J. 23 (10), 941-955.

Finkle, T.A., 1998. The relationship between boards of directors and initial public offering in the biotechnology industry. *. Enterpren. Theor. Pract. 22, 5-29.

Firth, M., Liau-Tan, C.K., 1998. Auditor quality, signaling, and the valuation of initial public offerings. *. J. Bus. Finance Account. 25 (1-2), 145-165.

Filatotchev, I., 2005. Effects of executive characteristics and venture capital involvement on board composition and share ownership in IPO firms. *. Br. J. Manag. 17 (1), 75-92.

Fischer, H.M., Pollock, T.G., 2004. Effects of social capital and power on surviving transformational change: the case of initial public offering. *. Acad. Manag. J. 47 (4), 463-481.

Florin, J., 2005. Is venture capital worth it? Effects on firm performance and founder returns. *. J. Bus. Ventur. 20 (1), $113-135$.

Florin, J., Lubatkin, M., Schulze, W., 2003. A social capital model of high-growth ventures. *. Acad. Manag. J. 46 (3), 374-384.

Florin, J., Simsek, Z., 2007. The effects of moral hazard and adverse selection on the pricing and underpricing of initial public offerings. *. Venture Cap. 9 (2), $127-143$.

Fohlin, C., 2000. IPO Underpricing in Two Universes Berlin, 1882-1982, and New York 1998- 2000. *. (Working paper).

Frye, M.B., 1999. Essays on the effectiveness of corporate governance mechanisms in initial public offerings. *. Dissertation.

Fung, S.Y.K., Gul, F.A., Radhakrishnan, S., 2007. Investment Banks' Repeated IPO Business Opportunities and IPO Underpricing. *. Working Paper.

Garfinkel, J.A., 1993. IPO underpricing, insider selling and subsequent equity offerings: is underpricing a signal of quality? *. Financ. Manag. 22, 74-83.

Givoly, D., Shi, C., 2007. Accounting for software development costs and the cost of capital: evidence from IPO underpricing in the software industry. *. J. Account. Audit Finance 23 (2), 271-304.

Gounopoulos, C., 2003. The initial and aftermarket performance of IPOs: evidence from Athens stock exchange. *. Work. Pap.

Gounopoulos, C., Nounis, G., Stylianides, P., 2007. The short and long term performance of initial public offerings in the Cyprus stock exchange. *. Journal of Financial Decision Making 4.

Gulati, R., Higgins, M.C., 2003. Which ties matter when? The contingent effects of interorganizational partnerships on IPO success. *. Strat. Manag. J. 24 (2), 127-144. Hebb, G.M., MacKinnon, G.H., 2004. Valuation uncertainty and IPOs: investment bank versus commercial bank underwriters. *. J. Econ. Finance 28 (1), $68-87$. Heeley, M.B., Matusik, S.F., Jain, N., 2007. Innovation, appropriability, and the underpricing of initial public offerings. *. Acad. Manag. J. 50 (1), $209-225$. Hegde, S.P., Varshney, S.B., 2003. Ownership structure, underpricing, and market liquidity of new equity issues. *. Stud. Econ. Finance 21 (1), 1-39. Higgins, M.C., Gulati, R., 2003. Getting off to a good start: the effects of upper echelon affiliation on underwriter prestige. *. Organ. Sci. 14 (3), 244-263.

Higgins, M.C., Gulati, R., 2006. Stacking the deck: the effects of top management backgrounds on investor decisions. *. Strat. Manag. J. 27 (1), 1-25.

Hunter, J.E., Schmidt, F.L., 1994. Correcting for sources of artificial variation across studies. In: Cooper, H., Hedges, L.V. (Eds.), The Handbook of Research Synthesis. Russell Sage Foundation, New York, pp. 324-336.

Francis, B., Hasan, I., Li, F., 2001. Underpricing of foreign and domestic IPOs in the U.S. market: empirical evidence. *. Financ. Mark. Inst. Instrum. 10 (1), 1-18. Hill, P., Wilson, N., 2007. Value gains on flotation and IPO underpricing, value gains on flotation and IPO underpricing. *. J. Bus. Finance Account. 33 (9-10), $1435-1459$.

How, J.C.Y., Low, J.G., 1993. Fractional ownership and underpricing: signals of IPO firm value? *. Pac. Basin Finance J. 1 (1), $47-65$.

Hursti, J., Maula, M.V.J., 2007. Acquiring financial resources from foreign equity capital markets: an examination of factors influencing foreign initial public offerings. *. J. Bus. Ventur. $22(6)$.

Jain, B.A., Jayaraman, N., Kini, O., 2008. The path-to-profitability of Internet IPO firms. *. J. Bus. Ventur. 23 (2), 165-194.

James, C., 1992. Relationship-specific assets and the pricing of underwriter services. *. J. Finance 47 (5), $1865-1885$.

Kiymaz, H., 2000. The initial and aftermarket performance of IPOs in an emerging market: evidence from Istanbul stock exchange. *. J. Multinatl. Financ. Manag. 10 (2), 213-227.

Koh, F., Lim, J., Chin, N., 1992. The signaling process in initial public offerings. *. Asia Pac. J. Manag. 9 (2), $151-165$.

Kor, Y.Y., 2006. Direct and interaction effects of top management team and board compositions on R\&D investment strategy. *. Strat. Manag. J. 27 (11), $1081-1099$.

Kor, Y.Y., Mahoney, J.T., 2005. How dynamics, management, and governance of resource deployments influence firm-level performance. *. Strat. Manag. J. 26 (5), $489-496$.

Kor, Y.Y., Mahoney, J.T., Watson, S., 2008. The effects of demand, competitive, and technological uncertainty on board monitoring and institutional ownership of IPO firms. *. J. Manag. Govern. 12 (3), 239-259.

Krinsky, I., Rotenberg, W., 1988. The valuation of initial public offerings. *. Contemp. Account. Res. 5 (2), $501-515$.

Kroll, M., Walters, B.A., Le, S.A., 2007. The impact of board composition and top management team ownership structure on post-IPO performance in young entrepreneurial firms. *. Acad. Manag. J. 50 (5), 1198-1216.

Latham, S., Braun, M.R., 2010. To IPO and not to IPO: risks, uncertainty and the decision to go public. *. Br. J. Manag. 21 (3), $666-683$.

Larraza-Kintana, M., Wiseman, R.M., Gomez-Mejia, L.R., Welbourne, T.M., 2007. Disentangling compensation and employment risks using the behavioral agency model. *. Strat. Manag. J. 28 (10), 1001-1019.

Lester, R.H., Certo, S.T., Dalton, C.M., Dalton, D.R., Cannella, A.A., 2006. Initial public offering investor valuations: an examination of top management team prestige and environment uncertainty. *. J. Small Bus. Manag. 44 (1), 1-26.

Li, J., 2004. A power model of management team restructuring and executive exit in IPO-stage firms: antecedents and performance effects. *. Dissertation.

Li, Y., McConomy, B.J., 2004. Simultaneous signaling in IPOs via management earnings forecasts and retained equity: an empirical analysis of the substitution effect. *. J. Account. Audit Finance 19 (1), 1-28.

Li, S.X., Rowley, T.J., 2002. Inertia and evaluation mechanisms in interorganizational partner selection: syndicate formation among US investment banks. *. Acad. Manag. J. 45 (6), 1104-1119.

Lin, Z.J., Tian, Z., 2012. Accounting conservatism and IPO underpricing: China evidence. *. J. Int. Account. Audit. Taxat. 21, 127-144. 
Mauer, D.C., Senbet, L.W., 1992. The effect of the secondary market on the pricing of initial public offerings: theory and evidence. *. J. Financ. Quant. Anal. 27 (1), 55-79.

McBain, M.L., Krause, D.S., 1989. Going public: the impact of insiders' holdings on the price of initial public offerings. *. J. Bus. Ventur. 4 (6), 419-428.

McGuinness, P., 1992. An examination of the underpricing of initial public offerings in Hong Kong: 1980-90. *. J. Bus. Finance Account. 19 (2), 165-186.

Mohan, N.J., Chen, C.R., 2001. Information content of lock-up provisions in initial public offerings. *. Int. Rev. Econ. Finance 10 (1), $41-59$.

McGuinness, P., 1993. The market valuation of initial public offerings in Hong Kong. *. Appl. Financ. Econ. 3 (3), $267-281$.

Mudambi, R., Treichel, M.Z., 2005. Cash crisis in newly public Internet-based firms: an empirical analysis. *. J. Bus. Ventur. 20 (4), 543-571.

Muzatko, S.R., Johnstone, K.M.J., Mayhew, B.W., Rittenberg, L.E., 2004. An empirical investigation of IPO underpricing and the change to the LLP organization of audit firms. *. Audit J. Pract. Theor. 23 (1), 53-67.

Nandha, M.S., Sawyer, K.R., 2002. Ex-ante uncertainty in initial public offerings: the Indian Market. *. Finance India 16 (3), $961-976$.

Nelson, T., 2003. The persistence of founder influence: management, ownership, and performance effects at initial public offering. *. Strat. Manag. J. 24 (8), 707-724.

Ng, P.P.H., Fung, S.M., Tai, B.Y.K., 1994. Auditing firm reputation and the underpricing of initial public offerings in Hong Kong: $1989-1991$. *. Int. J. Account. 29 (3), $220-233$.

Nikbakht, E., Shahrokhi, M., Martin, R., 2007. IPO pricing and executive compensation. *. Int. J. Bus. 12 (3), 311-324.

Pollock, T.G., Rindova, V.P., 2003. Media legitimation effects in the market for initial public offerings. *. Acad. Manag. J. 46 (5), $631-642$.

Pollock, T.G., Chen, G., Jackson, E.M., Hambrick, D.C., 2010. How much prestige is enough? Assessing the value of multiple types of high-status affiliates for young firms. *. J. Bus. Ventur. 25 (1), 6-23.

Pollock, T.G., Rindova, V.P., Maggitti, P.G., 2008. Market watch: information and availability cascades among the media and investors in the US IPO market. *. Acad. Manag. J. 51 (2), 335-358.

Petersen, M., 2007. Is underpricing a deliberate choice? Evidence from Germany. *. Work. Pap.

Pound, J., 1992. Beyond takeovers: politics comes to corporate control. Harv. Bus. Rev. 70 (2), $83-93$.

Rasheed, A.M.A., Datta, D.K., Chinta, R.R., 1997. Determinants of price premiums: a study of initial public offerings in the medical diagnostics and devices industry. * J. Small Bus. Manag. 35 (4), 11-23.

Reber, B., Berry, B., Toms, S., 2005. Firm resources and quality signaling: evidence from UK initial public offerings. *. Appl. Financ. Econ. 15 (8), 575-586.

Reber, F., Fong, C., 2006. Explaining mispricing of initial public offerings in Singapore. *. Appl. Financ. Econ. 16 (18), $1339-1353$.

Reuer, J.J., Tong, T.W., Wu, C., 2012. A signaling theory of acquisition premiums: evidence from IPO targets. *. Acad. Manag. J. 55 (3), $667-683$.

Reutzel, C.R., Belsito, C.A., 2012. Examining the relative influence of upper echelons ties on IPO underpricing. Int. Enterpren. Manag. J. 8 (1), 1-14.

Roengpitya, R., Dalton, C.M., Dalton, D.R., Certo, S.T., 2007. The impact of external ownership on strategic outcomes in IPO firms. *. J. Appl. Manag. Enterpren. 12, 67-93.

Su, D., 2004. Leverage, insider ownership, and the underpricing of IPOs in China. *. J. Int. Financ. Mark. Inst. Money 14 (1), $37-54$.

Sanders, W.M.G., Boivie, S., 2004. Sorting things out: valuation of new firms in uncertain markets. *. Strat. Manag. J. 25 (2), $167-186$.

Su, D., Fleisher, B.M., 1999. An empirical investigation of underpricing in Chinese IPOs. *. Pac. Basin Finance J. 7 (2), $173-202$.

Ursel, N.D., Ljucovic, P., 1998. The impact of bank ownership of underwriters on the underpricing of initial public offerings. *. Canadian Journal of Administrative Sciences 15 (1), 17-27.

van der Goot, T., 2003. Risk, the quality of intermediaries and legal liability in The Netherlands IPO market. *. Int. Rev. Law Econ. 23 (2), $121-140$.

van der Zahn, J.L.W.M., Singh, I., Heniro, J., 2007. Is there an association between intellectual capital disclosure, underpricing and long-run performance? *. Journal of Human Resource Costing and Accounting 11 (3), 178-213.

Walters, B.A., Kroll, M., Wright, P., 2010. The impact of TMT board member control and environment on post-IPO performance. *. Acad. Manag. J. 53 (3), 572-595. Wan-Hussin, W.N., 2005. The effects of owners' participation and lockup on IPO underpricing in Malaysia. *. Asian Acad. Manag. J. 10, 19-36.

Welbourne, T.M., Andrews, A.O., 1996. Predicting the performance of initial public offerings: should human resource management be in the equation. *. Acad. Manag. J. 39 (4), 891-919.

Welbourne, T.M., Cyr, L.A., 1999. The human resource executive effect in initial public offering firms. *. Acad. Manag. J. 42 (6), $616-629$.

Williams, D.R., Duncan, W.J., Ginter, P.M., 2010. Testing a model of signals in the IPO offer process. *. Small Bus. Econ. 34 (4), $445-463$.

Wu, Y.H., Hsu, H.H., 2012. Corporate governance characteristics and underpricing: evidence from the AIM. *. Work. Pap.

Yang, Q., Zimmerman, M., Jiang, C., 2011. An empirical study of the impact of CEO characteristics on new firms' time to IPO. *. J. Small Bus. Manag. 49 (2), 163-184. Zhang, F., 2012. Information precision and IPO pricing. *. J. Corp. Finance 18 (2), 331-348.

Zhou, J., Elder, R., 2001. Audit Firm Size, Industry Specialization and Earnings Management by Initial Public Offering Firms. *. (Working Paper).

Zimmerman, M., 2008. The influence of top management team heterogeneity on the capital raised through an initial public offering. *. Enterpren. Theor. Pract. 32 (3), $391-414$.

Prof. dr. P.J. Engelen is affiliated with the University of Antwerp (Faculty of Business and Economics), and Utrecht University (School of Economics). He is the Program Director of the Master Program Financial Management at Utrecht University. His expertise focuses on Innovation Finance and on Institutions-based Corporate Finance. Recent research topics include IPOs, crowdfunding, real option modelling, corporate governance configurations, board diversity, corporate misconduct, reputation, CSR and business ethics.

Pursey Heugens is Professor of Organization Theory at the Rotterdam School of Management, Erasmus University. He received his PhD from the same institution in 2001. His research spans various theoretical research streams, including institutional, ecological, resource dependence, and bureaucracy theoretical perspectives. Empirically he primarily studies alternative forms of economic organization, notably family firms, business groups, professional service firms, and state-owned enterprises.

Marc van Essen(PhD Erasmus University) is an Associate Professor of International Business at the Moore School of Business, University of South Carolina and permanent visiting professor at EMlyon Business School, France. His research interests include international business, global strategy, corporate governance, and metaanalytic research methods.

Roxana Turturea is currently a Postdoc Researcher at Aalto University. Her research pertaining to entrepreneurial finance covers a wide range of contexts from crowdfunding to initial public offerings. Her research pertaining to corporate governance investigates how different forms of corporate governance (e.g., state ownership, block ownership) influence strategic decision-making in ways that ultimately affect firm performance.

Nicholas (Nick) Bailey is Assistant Professor of Management at the University of Northern Iowa. He received his PhD in International Business from the University of South Carolina. His research primarily focuses on the influence of government actors/institutions/systems on firm strategic decision-making and performance. 